\title{
Diagnosis and management of bronchopulmonary dysplasia
}

\author{
Margaret Gilfillan, ${ }^{1,2}$ Anita Bhandari, ${ }^{3,4}$ Vineet Bhandari5 ${ }^{5,6}$
}

Check for updates

${ }^{1}$ Division of Neonatology,

St Christopher's Hospital for Children, Philadelphia, PA, USA

${ }^{2}$ Drexel University College of Medicine, Philadelphia, PA, USA

${ }^{3}$ Division of Pulmonary and Sleep Medicine, Children's Hospital of Philadelphia, PA, USA

${ }^{4}$ Perelman School of Medicine, University of Pennsylvania, Philadelphia, PA, USA

${ }^{5}$ Division of Neonatology, The Children's Regional Hospital at Cooper, Camden, NJ, USA

${ }^{6}$ Cooper Medical School of Rowan University, Camden, NJ, USA

Correspondence to: $V$ Bhandari bhandari-vineet@cooperhealth.edu Cite this as: BMJ 2021;375:n1974 http://dx.doi.org/10.1136/bmj.n1974

Series explanation: State of the Art Reviews are commissioned on the basis of their relevance to academics and specialists

in the US and internationally. For this reason they are written predominantly by US authors.

\begin{abstract}
Bronchopulmonary dysplasia (BPD) is the most common chronic lung disease in infants and is associated with increased mortality, respiratory morbidity, neurodevelopmental impairment, and increased healthcare costs. In parallel with advances made in the field of neonatal intensive care, the phenotype of BPD has evolved from a fibrocystic disease affecting late preterm infants to one of impaired parenchymal development and dysregulated vascular growth predominantly affecting infants born before 29 weeks' gestational age. BPD has been shown to have significant lifelong consequences. Adults with BPD have been found to have abnormal lung function tests, reduced exercise tolerance, and may be at increased risk for developing chronic obstructive pulmonary disease. Evidence shows that BPD occurs secondary to genetic-environmental interactions in an immature lung. In this review, we evaluate the various clinical definitions, imaging modalities, and biomarker data that are helpful in making an early diagnosis of BPD. In addition, we evaluate recent evidence about the prevention and treatment of BPD. We discuss the invasive and non-invasive ventilation strategies and pharmacological agents used in the early, evolving, and established phases of BPD.
\end{abstract}

\section{Introduction}

Bronchopulmonary dysplasia (BPD) is the most common complication of prematurity, ${ }^{1}$ affecting up to $45 \%$ of infants born at $<29$ weeks' gestational age. $^{2}$ Although advances in care have led to improved survival, BPD incidence has remained static or even increased. ${ }^{3}$ BPD is not merely a lung disease, but a systemic condition with lifelong implications for adult health and quality of life. ${ }^{45}$ The healthcare costs associated with BPD are substantial ${ }^{6}$ and extend beyond the initial hospitalization. ${ }^{7}$ BPD lacks an objective definition for accurate prediction of future mortality and morbidity. ${ }^{8}$ The development of an optimal definition is challenging, given the complex multifactorial nature and variable clinical presentation of the disease. ${ }^{9}$ Frequently used definitions of BPD from the National Institutes of Health $\left(2001^{10}\right.$ and $\left.2018^{11}\right)$ rely on the subjectiveneed for various respiratory support modalities to identify and categorize severity of disease. This approach has important limitations. In this review, we appraise alternative models that could improve diagnostic accuracy and identify specific patterns of disease. Emerging approaches to diagnosis-proteomic, metabolomic, and microbiomic-are included in the review. We focus on existing interventions to prevent or mitigate the severity of $\mathrm{BPD}$, and evaluate the evidence and recommendations made based on the US Preventive Services Task Force grading (supplementary files: table 1). ${ }^{12}$

\section{Sources and selection criteria}

We searched the PubMed, Embase, and Cochrane databases for the dates 1967 to September 2020 for articles published in peer reviewed journals within the past two decades. Search terms included "bronchopulmonary dysplasia", "chronic lung disease of prematurity", "definition of bronchopulmonary dysplasia", "bronchopulmonary dysplasia and pulmonary hypertension", "bronchopulmonary dysplasia biomarkers", "bronchopulmonary dysplasia and postnatal steroids", "bronchopulmonary dysplasia and oxygen", "less invasive surfactant and bronchopulmonary dysplasia", "bronchopulmonary dysplasia and mechanical ventilation", "bronchopulmonary dysplasia and imaging”, "bronchopulmonary dysplasia and lung function testing", "bronchopulmonary dysplasia and diuretics", "bronchopulmonary dysplasia and bronchodilators", and "bronchopulmonary dysplasia guidelines". We chose to focus on the results of randomized controlled trials (RCTs) and systematic reviews with an emphasis on results published after 2010. We included results of well designed retrospective studies, and prioritized 
those that included at least 150 participants born before 29 weeks' gestational age. Animal studies were included to ascertain biological plausibility. We included consensus statements and clinical guidelines published in peer reviewed journals. We also searched the website www.clinicaltrials. gov using the terms "bronchopulmonary dysplasia" and "chronic lung disease of prematurity" to identify potential therapies currently undergoing investigation. We excluded articles not published in English and those that were not peer reviewed.

\section{Why is an accurate diagnosis of BPD important?}

The BPD phenotype has evolved, so that the emphysematous, fibrotic disease first described in $1967^{13}$ is less commonly seen in contemporary clinical practice. A "new" pattern, characterized by alveolar simplification and pulmonary vascular dysregulation with functional impairment, ${ }^{14}$ has become the predominant BPD phenotype encountered in neonatal intensive care units (NICUs). Rapid progress has been made in understanding the inciting, modulating, and mitigating factors that lead either to long term respiratory morbidity owing to lung repair, or healing and recovery (fig 1). Exposure to inflammation, ${ }^{15}$ placental vascular disease, ${ }^{16}$ hormonal deficiencies, ${ }^{17}$ genetics, ${ }^{18}$ and epigenetics $^{19}$ influence the relative vulnerability or resilience of the respiratory system prior to preterm birth. Events occurring in the postnatal period such as late onset infection with bacterial or viral agents ${ }^{20}$ can also have an adverse effect on short and long term outcomes. Variations in clinical care, including use of supplemental oxygen, ${ }^{21}$ positive pressure, ${ }^{22}$ medications, ${ }^{23}$ and nutrients, ${ }^{24}$ provoke responses modulated by genetic and epigenetic influences. Infants with BPD show substantial heterogeneity in clinical presentation and long term outcomes. ${ }^{25-27}$ The manner and precision with which BPD is defined have far-reaching consequences for translational and clinical research. ${ }^{8}$ For the clinician, an accurate diagnosis of BPD helps inform the use of specific respiratory support strategies and medications.

\section{Evaluation of the NIH 2018 criteria}

Early definitions of BPD relied on measures consistent with impairment of gas exchange in addition to radiographic abnormalities and clinical symptoms persisting for $>28$ days $^{28}$ (fig 2). In 1988, a single center retrospective study showed that continued use of supplemental oxygen at 36 weeks' post menstrual age (PMA) was more closely associated with abnormal pulmonary findings (as per the criteria listed in the study) upon long term follow-up in infants of $<32$ weeks' gestational age than earlier diagnostic models. ${ }^{29}$ This observation was incorporated in the Shennan 1988 definition, which is frequently used in clinical research. ${ }^{30}$ The NIH 2001 definition ${ }^{10}$ diagnoses BPD if supplemental oxygen has been required for at least 28 days. The severity of disease is graded "mild", "moderate", or "severe” at 36 weeks' PMA, or discharge for infants born at <32 weeks, or day of life (DOL) 56 for infants $>32$ weeks' gestational age, according to the need for respiratory support. ${ }^{10}$

Studies that compare the NIH 2001 criteria ${ }^{10}$ with the 28 days $^{28}$ and the Shennan 1988 definitions $^{29}$ are summarized in table $1 .^{31-33}$ The incidence of

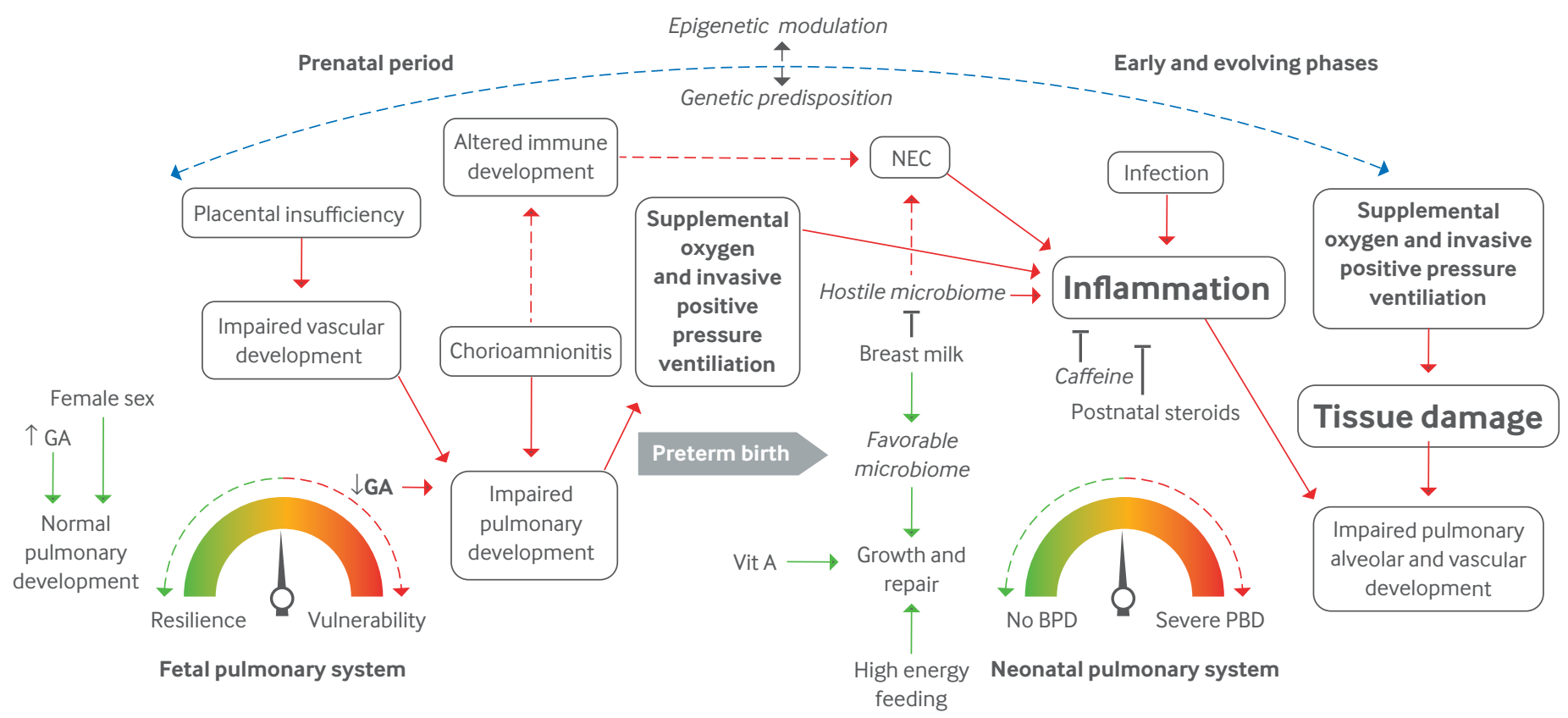

Fig 1 | A summary of the inciting, protective, and modulating factors that influence the development of BPD. Prenatal factors that lead to impaired lung development have an impact on the postnatal course, increasing the likelihood of exposure to invasive mechanical ventilation and supraphysiological oxygen. Exposure to inflammation in utero also alters immune development and may predispose to a dysregulated prolonged response to relatively minor stimuli. Responses to injurious and protective influences are modulated by genetic and epigenetic mechanisms. $\mathrm{BPD}=$ bronchopulmonary dysplasia; $\mathrm{GA}=$ gestational age, $\mathrm{NEC}=$ necrotizing enterocolitis; Vit $\mathrm{A}=$ vitamin $\mathrm{A}$ 
Walsh 2004

Physiological definition

An infant $\leq 32$ weeks' GA

who at 36 weeks' PMA

either requires IMV/CPA-

$\mathrm{P} / \mathrm{FiO}_{2} \geq 0.3$ or fails to

maintain $\mathrm{O}_{2}$ saturation

$\geq 90 \%$ in for 30 mins

following oxygen

reduction test
NIH 2018 definition

An infant $\leq 32$ weeks' GA with persistent radiographic findings of parenchymal lung disease who requires respiratory support at 36 weeks' PMA for $\geq 3$ days to maintain arterial $\mathrm{O}_{2}$ saturation $90-95 \%$

Dependent on supplemental oxygen at 36 weeks' PMA

\begin{tabular}{|c|c|c|c|c|}
\hline & IMV & $\begin{array}{l}\text { CPAP, NIPPV, } \\
\text { NC } \geq 3 \text { LPM }\end{array}$ & $\begin{array}{l}\text { NC 1- } \\
2 \text { LPM }\end{array}$ & $\begin{array}{l}\text { NC } \\
\text { ILPM }\end{array}$ \\
\hline Grade I & & 0.21 & $0.22-0.29$ & $0.22-0.7$ \\
\hline Grade II & 0.21 & $0.22-0.29$ & $\geq 0.3$ & $\geq 0.7$ \\
\hline
\end{tabular}

Grade III $>0.21 \geq 0.3$

Grade III $>0.21$

Grade Illa Death $>14$ days of life $<36$ weeks' PMA from respiratory failure

\section{8}

radiographic and

histological changes

1967

\section{9}

Tooley 1979

Radiographic abnormality of the lung at 30 days $\mathrm{PaO} 2<60 \mathrm{mmHg}$ in $\mathrm{RA}$ or $\mathrm{PCO} 2$ $<45 \mathrm{mmHg}$ Oxygen dependent at 30 days of life

\section{4}

Fig 2 | Evolution in complexity of proposed definitions of BPD over time. BPD=bronchopulmonary dysplasia; GA=gestational age; IMV=invasive mechanical ventilation; $\mathrm{CPAP}=$ continuous positive airway pressure; $\mathrm{FiO}_{2}=$ fraction of inspired oxygen; $\mathrm{NIPPV}=$ nasal intermittent positive pressure ventilation; $N C=$ nasal cannula; $L P M=$ liters per minute; $P M A=$ post menstrual age; $R A=$ room air

mortality, growth failure, and neurodevelopmental impairment (NDI) was increased with statistical significance in infants with severe BPD. ${ }^{31}$ Other studies have linked severe BPD to NDI, indicating meaningful prognostic information. ${ }^{34}$ The 28 days definition increases the sensitivity, but decreases

\begin{tabular}{|c|c|c|c|c|}
\hline Reference & Study population & Definition used & Incidence & $\begin{array}{l}\text { Relative predictive value for use of } \\
\text { pulmonary medications and hospital } \\
\text { readmission }\end{array}$ \\
\hline \multirow[t]{6}{*}{31} & \multirow{6}{*}{$\begin{array}{l}4866 \text { infants }<32 \text { weeks' GA, }<1000 \mathrm{~g} \text { birth weight } \\
\text { Born } 1995-1999 \\
\text { Follow-up information for } 3848 \text { infants available }\end{array}$} & Oxygen for 28 days $^{28}$ & $77 \%$ & $\begin{array}{l}\text { Sens }++++ \\
\text { Spec }+\end{array}$ \\
\hline & & Shennan ${ }^{29}$ & $44 \%$ & $\begin{array}{l}\text { Sens }+++ \\
\text { Spec }+++\end{array}$ \\
\hline & & $\mathrm{NIH} 2001^{10}$ & $77 \%$ & $\begin{array}{l}\text { Sens }++++ \\
\text { Spec }+\end{array}$ \\
\hline & & Mild & $31 \%$ & Risk insignificant \\
\hline & & Moderate & $30 \%$ & Risk $1.5-2 \times$ that of no BPD \\
\hline & & Severe & $16 \%$ & Risk at least $2 \times$ that of no BPD \\
\hline \multirow[t]{6}{*}{32} & \multirow[t]{6}{*}{$\begin{array}{l}765 \text { infants } 23+0 \text { to } 28+6 \text { weeks' GA prospectively enrolled in a multicenter } \\
\text { research cohort }\end{array}$} & $\begin{array}{l}\text { Shennan } \\
\% \text { unclassifiable }\end{array}$ & $\begin{array}{l}41 \% \\
2.9 \% \\
\end{array}$ & \multirow[t]{6}{*}{ NA } \\
\hline & & $\begin{array}{l}\text { Physiological } \\
\% \text { unclassifiable }\end{array}$ & $\begin{array}{l}32 \% \\
16 \%\end{array}$ & \\
\hline & & $\begin{array}{l}\mathrm{NIH} 2001 \\
\% \text { unclassifiable }\end{array}$ & $\begin{array}{l}58.6 \% \\
2.1 \%\end{array}$ & \\
\hline & & Mild & $19.5 \%$ & \\
\hline & & Moderate & $11.6 \%$ & \\
\hline & & Severe & $27.5 \%$ & \\
\hline \multirow[t]{5}{*}{33} & \multirow{5}{*}{$\begin{array}{l}247 \text { infants } \leq 30 \text { weeks admitted to a level IV neonatal intensive care unit 2013- } \\
2015\end{array}$} & Shennan & $39 \%$ & \multirow[t]{5}{*}{ NA } \\
\hline & & NIH 2001 & $71 \%$ & \\
\hline & & Mild & $17 \%$ & \\
\hline & & Moderate & $44 \%$ & \\
\hline & & Severe & $49 \%$ & \\
\hline
\end{tabular}


specificity, of adverse outcome prediction in mild BPD, compared with Shennan 1988. ${ }^{30} 31$

Comparing NIH 2001, physiological, and Shennan 1988 definitions showed considerable barriers to their use in current clinical practice. ${ }^{32}$ Around 2-16\% of infants were not classified because of variations in the use of nasal cannula and failure to perform an oxygen reduction test (ORT) (table 1); thus, this makes a strong argument for a new consensus definition to encompass contemporary respiratory strategies.

A workshop sponsored by the National Institute for Child Health and Human Development (NICHD) led to a revised definition (NIH 2018) ${ }^{11}$ (fig 2). High flow nasal cannula (HFNC) and severely affected infants who die from respiratory causes prior to 36 weeks' PMA were included in the definition. Supplemental oxygen need for 28 days was removed as it lacks precision in predicting long term outcomes, ${ }^{31}$ and is often misinterpreted as need for oxygen on DOL $28 .^{30}$ Instead, infants with persistent radiographical evidence of parenchymal lung disease who remained on respiratory support were classified according to the therapy required to maintain oxygen saturation $\left(\mathrm{SpO}_{2}\right)$ at $90-95 \%$ at 36 weeks' PMA. ${ }^{11}$ One major change proposed was that infants would need to be on the stated respiratory support for a minimum of three consecutive days with the intent of minimizing up- or down-classification based on acute clinical events.

Use of the NIH 2018 criteria identified a greater proportion of patients than either the Shennan 1988 or NIH 2001 definitions. ${ }^{35}$ Infants who were diagnosed BPD of any grade using the NIH 2018 criteria were more likely to develop other comorbidities than those without BPD $(\mathrm{P}<0.001)$ suggesting a high degree of sensitivity in predicting short term outcomes. The ability of the NIH 2018 definition of BPD to predict long term outcomes has not been assessed.

Several limitations remain. ${ }^{36}$ Firstly, the decision for respiratory support still lies with the clinician. Decisions about the need for respiratory support are often based on subjective assessment of the infant's work of breathing, frequency of apnea/bradycardic events, ability to take adequate oral feeds, or maintenance of an optimal growth trajectory. At 36 weeks' PMA, preterm infants may still have immature respiratory control that manifests as periodic breathing or apneic events. Diuretics ${ }^{37}$ and bronchodilators ${ }^{38}$ may influence the need for respiratory support, and their use varies markedly between centers ${ }^{39}$ and may influence reporting of BPD. The revised definition also fails to differentiate infants with BPD associated pulmonary hypertension (BPD-PH). The European Pediatric Pulmonary Vascular Disease Network (EPPVDN) recommends an evaluation for any infant of <28 weeks' gestational age with severe respiratory compromise at 36 weeks' PMA, and at discharge in those with established BPD. ${ }^{40}$ Transthoracic echocardiography (TTE) can identify infants at risk of BPD-PH as early as DOL
$7 .^{41}$ TTE screening in a clinical BPD definition may provide more accurate prognostic information, given the increased incidence of adverse outcomes associated with BPD-PH. ${ }^{25} 27$ Variation in the mean airway pressure generated by different modes of noninvasive support-for example, HFNC versus nasal intermittent positive pressure ventilation (NIPPV) - could lead to significant phenotypic heterogeneity. The degree of positive pressure required could signify large airway disease such as tracheomalacia, ${ }^{42}$ underlying parenchymal disease, or immature respiratory control.

\section{Alternative clinical definitions for BPD}

One of the main criticisms leveled at NIH 2018 was the use of semi-quantitative categories and arbitrary thresholds to assign disease severity, rather than the creation of a model based on critical outcomes such as death and NDI. ${ }^{36}$ In a retrospective study that tested 18 potential definitions against outcome data obtained from the NICHD Neonatal Research Network, ${ }^{43}$ the models tested were found to predict late death or serious respiratory morbidity with a c-statistic ranging from 0.741 to 0.785 . A model that defined severity by the support mode at 36 weeks' PMA without reference to oxygen requirement was found to correlate most closely with adverse outcomes, predicting death or serious respiratory morbidity in $81 \%$ of study infants. This optimal definition (table 2), referred to as Jensen 2019, was also most effective in the prediction of late death or NDI with a c-statistic of 0.747 . Consistent with evidence linking chronic mechanical ventilation to cerebral palsy, ${ }^{44}$ the population of infants who remain on invasive mechanical ventilation at 36 weeks' PMA is at particularly high risk for adverse outcomes. The ability of Jensen 2019 to separate infants dependent on invasive versus non-invasive ventilation or nasal cannula with a fraction of inspired oxygen $\left(\mathrm{FiO}_{2}\right)>0.3$ would be of benefit when evaluating the impact of novel therapies designed to mitigate the severity of BPD. These criteria also have the benefit of being easy to apply in clinical practice and in research studies because of the omission of the ORT.

Some important limitations include that these criteria were tested on infants born at gestational age $<32$ weeks, and most were $\leq 27$ weeks. Jensen 2019 may therefore lack sensitivity and specificity in predicting outcomes in infants born at $>27$ weeks' gestational age. The choice of 36 weeks as a time point for assessment continues to offer potential for infants to be "up-classified" for needing respiratory support to compensate for impaired control of breathing or difficulties coordinating oral feeding. A retrospective study utilizing data from the Canadian Neonatal Network suggested that allowing for assessment at 40 weeks' PMA may improve the predictive value of a BPD diagnosis. ${ }^{45}$ The need for oxygen or respiratory support $\geq$ nasal cannula 1.5 liters/minute at 36 weeks' PMA was found to have the greatest value in predicting serious respiratory 


\begin{tabular}{|c|c|c|c|c|c|c|c|}
\hline & \multicolumn{5}{|c|}{$\begin{array}{l}\text { Treatment with the following support at } 36 \text { weeks PMA or at discharge, whichever } \\
\text { comes first }\end{array}$} & \multicolumn{2}{|c|}{$\begin{array}{l}\text { Predictive accuracy of definition } \\
\text { (c-statistic) }\end{array}$} \\
\hline & \multirow[b]{2}{*}{$\begin{array}{l}\text { RA: } \\
\text { Mild BPD: } \geq 21 \% \\
\mathrm{FiO}_{2} \text { for } \geq 28 \text { days } \\
\mathrm{No}^{\text {BPD: }} \text { no } 28 \text { day } \\
\text { assessment }\end{array}$} & $N C \leq 2 L P M$ & \multirow[t]{2}{*}{$N C \geq 2 L P M$} & \multirow{2}{*}{$\begin{array}{l}\text { nCPAP } \\
\text { NIPPV }\end{array}$} & \multirow[t]{2}{*}{ IMV } & \multirow{2}{*}{$\begin{array}{l}\text { Mortality or serious } \\
\text { respiratory morbidity }\end{array}$} & \multirow{2}{*}{$\begin{array}{l}\text { Mortality or } \\
\text { moderate to } \\
\text { severe NDI }\end{array}$} \\
\hline & & $\mathrm{FiO}_{2}<0.3$ & & & & & \\
\hline $\begin{array}{l}\text { NIH } 2001 \\
\text { definition }\end{array}$ & Mild BPD & Moderate BPD & Severe BPD & & & 0.741 & 0.727 \\
\hline $\begin{array}{l}\text { Jensen et al } \\
\text { alternative } \\
\text { definition }\end{array}$ & No BPD & Grade 1 BPD & Grade 2 BPD & & $\begin{array}{l}\text { Grade } 3 \\
\text { BPD }\end{array}$ & $0.785^{\star}$ & $0.747^{\star}$ \\
\hline
\end{tabular}

morbidity (adjusted odds ratio (AOR) 3.4, 95\% confidence interval $(95 \% \mathrm{CI}) 1.8$ to 6.3$)$. Only $2.5 \%$ of infants who did not meet criteria for BPD went on to develop serious respiratory morbidity according to the study definition. The need for supplemental oxygen or respiratory support at 36 weeks' PMA was found to have marginally greater accuracy in predicting serious neurosensory impairment than other "traditional" BPD definitions (AOR 1.7, 95\% CI 1.2 to 2.4$).{ }^{45}$ When the criteria of supplemental oxygen and/or respiratory support with $>1.5$ liters/ minute by nasal cannula was applied at different gestational ages, improved ability to predict severe respiratory morbidity was noted at 40 weeks' PMA (AOR 6.4, 95\% CI 3.4 to 11.0). The optimal time to apply the criteria for prediction of severe neurosensory morbidity was noted to be at 37 weeks' gestational age (area under the curve or $\mathrm{AUC}=0.743$, AOR 1.8, 95\% CI 1.3 to 2.6); however, application of the definition at 40 weeks yielded similar results (AUC $=0.74$, AOR $1.5,95 \%$ CI 1.0 to 2.1). This is perhaps not surprising, as an evaluation performed later in time is more likely to be predictive of a more distant event. An ORT was not routinely performed, limiting accuracy of the data. One of the greatest difficulties in moving the time point of assessment to 40 weeks is that many infants will have already met criteria for discharge. Those who are breathing room air without support at 36 weeks' PMA are unlikely to require oxygen or support at 40 weeks' PMA. However, infants with a relatively modest oxygen requirement who meet all other prerequisites for discharge may be anomalously classified as BPD, if assessment is delayed for several weeks.

In summary, the NIH 2001 definition of BPD is poorly reflective of current respiratory support strategies $^{32}$ with the "mild" category of BPD having limited predictive value for long term morbidity. ${ }^{31}$ The NIH 2018 definition ${ }^{11}$ is more easily applicable to contemporary neonatal care; however, these criteria have yet to be validated with long term outcomes in a large preterm population. The accuracy in predicting long term outcomes could be improved by moving the assessment from 36 to 40 weeks' PMA. ${ }^{45}$ However, this could make obtaining information on infants who are discharged earlier on supplemental oxygen problematic. The evidence based Jensen 2019 definition seems the most promising in providing a relatively simple means of predicting outcomes. ${ }^{43}$ Further discussions regarding refinements to clinical definitions should be informed by both the Jensen $2019^{43}$ and the 40 weeks' PMA evidence based definitions. ${ }^{45}$

\section{Physiological measurements in the diagnosis of BPD}

A physiological definition for $\mathrm{BPD}$ using $\mathrm{SpO}_{2}$ during an ORT was first described in a single center prospective observational study in 2003, and a refined version applied in a larger multicenter prospective observational study. ${ }^{46}$ Infants requiring $\mathrm{FiO}_{2}>0.3$ or invasive mechanical ventilation or continuous positive airway pressure (CPAP) to maintain $\mathrm{SpO}_{2}$ at 90-95\% at 35-37 weeks' PMA were classified as having BPD. Infants on nasal cannula 1-2 liters/minute who either required $\mathrm{FiO}_{2}<0.3$ at rest to maintain $\mathrm{SpO}_{2} 90-96 \%$ or were maintaining saturations $>96 \%$ breathing $\mathrm{FiO}_{2}>0.3$ were eligible to undergo an ORT. Those who maintained $\mathrm{SpO}_{2} \geq$ $90 \%$ breathing $\mathrm{FiO}_{2} 0.21$ for 30 minutes were then classified as "no BPD." ${ }^{26}$ Use of the physiological definition was found to result in a significant decrease in the rate of diagnosis (mean reduction 10\%; range $0-44 \%$ ) and reduced variation in incidence of BPD between institutions. ${ }^{46}$ One potential limitation of the physiological definition when compared with the NIH 2001 classification is the binary outcome of "BPD" versus "no BPD." A more nuanced method that evaluates $\mathrm{SpO}_{2}$ during a stepwise reduction of supplemental oxygen in order to derive the degree of right shift of the oxygen saturation curve, ventilation perfusion ratio $(\mathrm{Va} / \mathrm{Q})$, and right-left shunt in preterm infants has been evaluated in a prospective observational study. ${ }^{47}$ Right shift, and the magnitude of the right-left shunt was found to increase and Va/Q found to decrease in accordance with BPD severity as per the NIH 2001 definition. ${ }^{47}$ Although the "shift test" is non-invasive and can be performed in 25-30 minutes, it does require the use of an oxygen analyzer 
and is yet to be validated in a large population of preterm infants. Although the ORT and the "shift test" offer potential as non-invasive objective tests, these may not be easily incorporated in research or clinical care. A prospective cohort study enrolled in the Prematurity and Respiratory Outcome Program showed that $32 \%$ of infants met the criteria for "physiological" BPD compared with 58.6\% and 40.8\% with NIH 2001 or Shennan 1988 definitions, respectively. ${ }^{32}$ A recent systematic review found that only $5 \%$ of studies conducted between 2010 and 2015 reported "physiological" BPD as an outcome. ${ }^{30}$ An observational study revealed significant episodes of periodic breathing in $43.2 \%$ of infants who failed the ORT. ${ }^{48}$ This finding indicates immature respiratory control may be an important confounding factor limiting the validity of the physiological definition.

Pulmonary function testing has been proposed to gain meaningful information in the diagnosis of BPD and validation of proposed definitions. ${ }^{49} 50$ Preterm birth and very low birth weight (VLBW) status have been consistently associated with diminished lung capacity, ${ }^{51-53}$ increased airway obstruction, ${ }^{51-54}$ impaired gas exchange, ${ }^{51}$ and a premature decline in respiratory function. ${ }^{5354}$ Longitudinal assessment by lung function and respiratory questionnaire has played a role in BPD outcomes ${ }^{55}$; ; however, it is limited by the need for specialist equipment and expertise. ${ }^{50}$ Serial measures of lung function and assessment of respiratory morbidity should form part of the routine follow-up of infants with BPD. ${ }^{57}$

\section{Radiographical studies in the prediction of BPD}

Among imaging modalities, plain chest radiography and computed tomography scanning remain the most extensively studied in BPD. ${ }^{58}$ Several different radiographic abnormalities have been associated with continued oxygen requirement at 36 weeks' PMA, including chronic pulmonary edema $^{59}$ and a "bubbly" cystic appearance. ${ }^{59} 60 \mathrm{~A}$ scoring system applied to radiographs on DOL 7 was found to correlate better with BPD diagnosis at DOL 28 than certain readily available clinical data. ${ }^{61}$ A pattern of interstitial pneumonitis noted on DOL 7 was independently associated with the combined outcome of death before 36 weeks' PMA or $\mathrm{BPD}$ (odds ratio [OR] 4.0, 95\% CI 1.1 to 14.4$)^{62}$ Measurement of the chest radiograph thoracic area (CRTA) has potential as a quantitative predictor of altered pulmonary mechanics. ${ }^{63} 64$ Elevated CRTA obtained from radiographs in the first 48 hours of life and decreased functional residual capacity (FRC) on DOL 3 was associated with BPD in intubated preterm infants. ${ }^{63}$ Increased CRTA and decreased FRC were indicative of gas trapping with low functional lung volumes. Reduced FRC had strong predictive value for the development of moderate to severe BPD. Increased CRTA measurements in preterm infants already meeting the criteria for BPD have been associated with impaired oxygenation. ${ }^{64}$ Using CRTA in combination with functional measurements may potentially be of use in the prediction of BPD.
Despite considerable drawbacks, computed tomography is recognized as the optimal method to obtain detailed pulmonary images. Several qualitative, ${ }^{65}$ semi-quantitative, ${ }^{66}$ and quantitative ${ }^{67}$ scoring systems have been proposed to predict the severity of long term respiratory outcome in BPD. ${ }^{58}$ Most scoring systems involve rating of the degree of peri-bronchial wall thickening, areas of decreased attenuation, and the presence and severity of bullae and bronchiectasis. Computed tomography scoring systems correlate with a range of adverse physiological and clinical outcomes including duration of oxygen therapy, ${ }^{66}$ desaturation events during sleep, ${ }^{67}$ incidence of wheezing, ${ }^{65}$ likelihood of hospital admission, ${ }^{65}$ clinical severity scores, ${ }^{66} 68$ and progressive decline in forced expiratory volume inone second $\left(\mathrm{FEV}_{1}\right)$ in patients who have had BPD. ${ }^{53}$ Although computed tomography findings were more specific for BPD than those of plain radiographs, ${ }^{66}$

${ }^{68}$ the considerable exposure to radiation, increased cost of the procedure, and need for either patient cooperation or deep sedation has limited the use of computed tomography. The European Respiratory Society (ERS) guidelines recommend follow-up imaging with ionizing radiation only in the most severely affected patients. ${ }^{57}$

In contrast, ultrasound does not require exposure to ionizing radiation and can be performed at the patient's bedside. An ultrasound scoring system involving evaluation of three different areas of the lung with a semi-quantitative score has shown some potential for predicting moderate to severe BPD. ${ }^{69}$ Lung ultrasound showed that failure of scores to improve with diuretic therapy was associated with worse respiratory outcome. ${ }^{70}$ If validated in a larger population, it could be useful in informing treatment as well as prognosis.

Ultra-short echo time (UTE) MRI has begun to emerge as an exciting new technique in respiratory imaging. ${ }^{71}$ MRI with UTE may provide a similar degree of information to computed tomography in preterm infants, without the disadvantages of exposure to ionizing radiation or deep sedation. ${ }^{72}$ Both structural and functional evaluation is possible, offering insight into the impact of cystic pulmonary lesions ${ }^{73}$ and tracheomalacia ${ }^{74}$ on respiratory mechanics. An MRI protocol identified an association between increased T2 and decreased T1 relaxation times to predict BPD with an AUC of $0.8 .^{75}$ Functional MRI could play a key role in defining specific phenotypes and may eventually replace chest computed tomography as the high resolution modality of choice for BPD.

\section{Biomarker based approaches}

The identification of various biomarkers ${ }^{76}$ or genomic, proteomic, metabolomic, ${ }^{77}$ or microbiomic $^{7879}$ signatures specific for BPD holds considerable promise as a strategy to develop a comprehensive, objective definition (table 3). It is already accepted that susceptibility to BPD is in part determined by genetic inheritance ${ }^{18}$ and the contribution of epigenetic mechanisms is also likely 
to be considerable. ${ }^{19} 89$ Among the advantages of biomarker and "omic" diagnostic strategies are the ability to identify markers of risk versus those of resilience at an early stage, and the potential to limit exposure to interventions with documented side effects. These measures could also offer a means by which to evaluate different disease phenotypes within the BPD population, and they remain an important focus for continued research.

\section{Management-early and evolving BPD \\ Use of supplemental oxygen}

Strategies that prevent BPD by interventions in the delivery room have strong potential to influence long term outcomes. ${ }^{90}$ Use of $\mathrm{FiO}_{2} 0.21$ for resuscitation of term infants is associated with improved outcomes, ${ }^{91}$ but for preterm infants, outcomes are uncertain. ${ }^{92}$ Data from a meta-analysis of RCTs that analyzed 251 and 253 infants who were enrolled in eight studies (six masked, two unmasked) in the lower and higher oxygen groups, however, have shown no advantage to initiation of resuscitation with $\mathrm{FiO}_{2} 0.3$ versus 0.6 in preventing $\mathrm{BPD}$ (RR 0.88, 95\% CI, 0.68 to 1.14 ), ${ }^{93}$ despite biological plausibility. ${ }^{94}$ Differences in methodology could have an important influence as, for example, mortality was found to be significantly lower in the low oxygen group in masked RCTs where oxygen was titrated by a researcher (RR 0.46 , 95\% CI, 0.23 to $0.92, \mathrm{P}=0.03$ ) and significantly higher in unmasked trials where oxygen was adjusted by the clinical team (RR 1.94 (1.02 to 3.68), $\mathrm{P}=0.04) .{ }^{93}$ At present, the only clear recommendation, based on an individual patient analysis of eight RCTs, is to initiate continuous monitoring of $\mathrm{SpO}_{2}$ promptly after birth and to titrate supplemental oxygen to achieve a $\mathrm{SpO}_{2}$ measurement of $>80 \%$ by 5 minutes of life given the association between hypoxia at this time point and increased mortality. ${ }^{95}$

Data from the Neonatal Oxygenation Prospective Meta-analysis collaborative study showed that use of the lower target range (85-89\%) was associated with increased risk for mortality prior to discharge (RR 1.17, 95\% CI 1.04 to $1.31, \mathrm{P}=0.01) .{ }^{96}$ Use of the higher saturation target (91-95\%) was not found to be associated with an increased incidence of "physiological" BPD. ${ }^{96}$ A systematic review and meta-analysis of five RCTs failed to show an impact of either a low or high saturation target on the incidence of BPD. ${ }^{97}$ Therefore, we recommend the use of saturation targets within the range $90-95 \%$ for infants requiring supplemental oxygen.

\section{Early respiratory support and surfactant administration}

Use of sustained inflations at birth in preterm neonates requiring delivery room resuscitation does not reduce the risk of BPD. ${ }^{98}$ Administration of exogenous surfactant has not shown a reduction in the incidence of BPD. ${ }^{99}$ Pooled results of three major RCTs comparing early CPAP with prophylactic surfactant administration ${ }^{100-102}$ found only marginal improvements in the incidence of BPD. ${ }^{103}$ Meta- analyses data have shown no advantage of early InSURE technique over initiation of CPAP. ${ }^{104}$ Minimally invasive surfactant treatment (MIST) and LISA techniques employ either a semi-rigid catheter or flexible feeding tube to deliver surfactant during spontaneous breathing, usually on nasal CPAP (nCPAP). ${ }^{105}$ The largest multicenter RCT that compared the outcomes of infants with extremely low birth weight receiving LISA with those receiving endotracheal surfactant did not find a significant reduction in BPD (67.3\% infants survived without BPD versus $58.7 \%$ in the control group, with an absolute risk reduction of $8.6 \%$ [95\% CI, $-5.0 \%$ to $21.9 \% ; \mathrm{P}=0.20$ ] in BPD. ${ }^{106}$ In another study, ${ }^{107}$ the greatest benefit of survival without BPD was in infants $26+0$ to $28+6$ weeks' gestational age. A systematic review of RCTs including 5598 infants in 30 studies showed that LISA may have significant benefit in reducing the composite outcome of death or BPD at 36 weeks' PMA (OR 0.49; 95\% credible interval [CrI], 0.30 to 0.79) and CPAP alone (OR 0.58; 95\% CrI 0.35 to 0.93$).{ }^{108}$ Few adverse effects have been reported with LISA, most being bradycardia during instillation of surfactant that can often be addressed by transiently pausing instillation and continuing over a slower time frame. ${ }^{105} \mathrm{~A}$ cohort study indicated that LISA is associated with a substantial increase in spontaneous intestinal perforation (SIP), most marked in infants of $<26$ weeks' GA (LISA $10.0 v$ ETT 7.4\%, $\mathrm{P}=0.029) .{ }^{109}$ This finding warrants further evaluation in a larger prospective RCT.

RCT and meta-analyses data support the early initiation of CPAP in the delivery room for those at risk of $\mathrm{BPD} .^{101-104}$ Meta-analyses data revealed a small but significant reduction in the outcome of BPD for infants who were initially supported with CPAP compared with those who were intubated and given surfactant, ${ }^{103}$ and a follow-up study ${ }^{101}$ revealed an association between CPAP use and reduced respiratory morbidity. ${ }^{56}$ The beneficial effect of nCPAP on long term respiratory outcomes may be underestimated owing to $33-50 \%$ of the infants randomized to nCPAP eventually requiring intubation and invasive mechanical ventilation. ${ }^{100}$ The likelihood of CPAP failure is highest in the most immature infants, ${ }^{110}$ and has been associated with increased risk of BPD. ${ }^{111}$ Among strategies that reduce the failure rate of nCPAP in infants of extremely low birth weight, aside from early use of caffeine, most are based on a physiological rationale rather than high quality RCT data. ${ }^{44}$ Various strategies can be used to generate CPAP-ventilator driven CPAP, use of a flow driver, and "bubble CPAP."112 Evidence to suggest superiority of any one CPAP modality over another is limited. Meta-analysis data have shown reduced failure rates of bubble CPAP compared with ventilator or flow driver regulated CPAP (RR 0.75, 95\% CI 0.57 to 0.98); however, use of bubble CPAP was not associated with reduced risk for BPD. ${ }^{113}$

NIPPV involves brief elevations of pressure above a baseline of nCPAP support and promotes respiratory stability by recruiting and stabilizing collapsed 


\begin{tabular}{|c|c|c|}
\hline Marker category & Specimen & Pattern conferring increased risk for BPD or BPD-PH \\
\hline \multirow{3}{*}{$\begin{array}{l}\text { Growth factors/vascular integrity } \\
\text { markers/nitric oxide pathway } \\
\text { markers }{ }^{128081}\end{array}$} & Cord blood & $\begin{array}{l}\text { Elevated: endostatin; decreased: Ang1, PIGF } \\
\text { Elevated: VEGF, PDGF-BB, BMP-10, FGF-19, } \mathrm{HGF}^{82}\end{array}$ \\
\hline & Blood & $\begin{array}{l}\text { Decreased: } L \text {-arginine, Ang1, FGF-18, PDGF-AA } \\
\text { Increased: Ang 2, nitrites }\end{array}$ \\
\hline & TA & Decreased: VEGF; elevated: VEGF receptor \\
\hline \multirow[t]{2}{*}{$\begin{array}{l}\text { Cytokines and pro-inflammatory } \\
\text { molecules }^{12} 808183\end{array}$} & Blood & $\begin{array}{l}\text { Elevated: IL-1 } \beta, \text { IL-6, IL-8, E-selectin, IFN } \gamma \text {, GCSF } \\
\text { Decreased: IL-17, RANTES, TNF- } \beta \text {, soluble L-selectin, } M C P-1\end{array}$ \\
\hline & TA & Elevated: IL-6, IL-8, NF-KB, MCP-1, MCP-2, MCP-3, IL-1 $\beta$ :ILRA ratio \\
\hline \multirow[t]{2}{*}{ Epithelial or fibrotic markers ${ }^{128081}$} & TA & $\begin{array}{l}\text { Elevated: MMP-8, MMP-9/TIMP-1, TGF } \\
\text { Decreased: TIMP-2, MMP-2, NGAL }\end{array}$ \\
\hline & Blood & Elevated: TGF $\beta$, KL-6, MMP/TIMP-1 \\
\hline Oxidant injury markers ${ }^{77}$ & TA & $\begin{array}{l}\text { Elevated: elastase, myeloperoxidase, xanthine oxidase, catalase, total sulfhydryls, epithelial lining carbonyls, } \\
\text { 3-chlorotyrosine, malondialdehyde }\end{array}$ \\
\hline Proteomic signatures $^{77}$ & TA & $\begin{array}{l}\text { Increased: surfactant protein-A2, annexin-3, calcium and integrin binding protein-1, } \\
\text { Decreased: leukocyte elastase inhibitor, calcyphosine }\end{array}$ \\
\hline \multirow[t]{3}{*}{ Metabolomic signatures $^{77}$} & Amniotic fluid & $\begin{array}{l}\text { Increased: leucinic acid, byproducts of fatty acid oxidation } \\
\text { Decreased: DHEAs, s-adenosylmethionine }\end{array}$ \\
\hline & Cord blood & $\begin{array}{l}\text { Increased: oxylipins, PGE1, PGE2, PGF2a, 9- and 13-HOTE, 9- and 13-HODE, and 9- and 13-KODE } \\
\text { Decreased: sphingomyelins, phospholipids }\end{array}$ \\
\hline & TA & $\begin{array}{l}\text { Increased: byproducts of fatty acid oxidation and estrogen and testosterone synthesis }{ }^{85} \text { histidine, glutamic acid, } \\
\text { citrulline, glycine and isoleucine, acyl carnitines (fatty acid oxidation), sphingolipids, sphingomyelin C18:1 and } \\
\text { C22:3, lysophosphatidylcholine } \\
\text { Volatile organic compounds detected by “electronic nose" }{ }^{87}\end{array}$ \\
\hline Microbiomic patterns ${ }^{77}$ & TA & $\begin{array}{l}\text { Increased: Enterobacteriae, Ureaplasma, Staphylococcus } \\
\text { Decreased: Lactobacillus }\end{array}$ \\
\hline Gene expression patterns ${ }^{7788}$ & Blood & $\begin{array}{l}\text { Increased: inflammatory response genes, CD44, phosphorus oxygen lyase activity, connective tissue mast cells } \\
\text { Decreased: T cell receptor related activation genes }\end{array}$ \\
\hline \multirow[t]{2}{*}{ Epigenetic markers ${ }^{77}$} & TA & $\begin{array}{l}\text { Elevated: miR-34a } \\
\text { Decreased: miR-876-3p, miR-378b, miR-20a-50, +miR-20b-5p, miR-1254, miR-1252-5p }\end{array}$ \\
\hline & Blood & Elevated: miR-219 \\
\hline \multicolumn{3}{|c|}{ 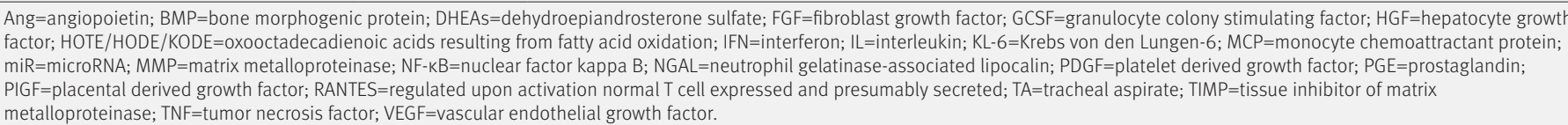 } \\
\hline
\end{tabular}

alveoli. ${ }^{114}$ Elevations in pressure can be either synchronized with the infant's own efforts (SNIPPV) or unsynchronized. When compared with NCPAP, systematic reviews have shown that early use of NIPPV is associated with reduced need for intubation in preterm infants. ${ }^{115116}$ However, this effect was not significantly associated with reduced risk for BPD. ${ }^{117}$

\section{Invasive mechanical ventilation}

If invasive mechanical ventilation cannot be avoided, the use of volume targeted ventilation (VTV) strategies should be strongly considered. ${ }^{118}$ A meta-analysis of 20 RCTs and quasi-randomized trials revealed that VTV was associated with reduced risk for the combined outcome of death or BPD at 36 weeks (RR 0.73, 95\% CI 0.59 to 0.89 , number needed to treat (NNT) 8, 95\% CI, 5 to 20). ${ }^{119}$

Primary use of high frequency ventilation (HFOV) in several RCTs was not consistently shown to decrease BPD. ${ }^{120}$ Primary use of HFOV was not associated with any significant improvement in lung function when evaluated between 16 and 19 years of age. ${ }^{121}$ No strong recommendations can therefore be made regarding use of elective HFOV in preterm infants at risk of BPD.

The requirement for invasive ventilation at DOL 7 has been shown consistently to be associated with increased risk for BPD. ${ }^{122} 123$ A single center retrospective study has shown that for infants of extremely low birth weight and <28 weeks' gestational age, extubation after DOL 8 is associated with a significantly increased hazard of developing BPD, compared with extubation between DOL 1 and 3 (hazard ratio (HR)16.9, 95\% CI 10.5 to 27.1, $\mathrm{P}<0.001$ ) and DOL 4-8 (HR 10.0, 95\% CI, 6.1 to 16.3; $\mathrm{P}<0.001) .{ }^{123} \mathrm{~A}$ similar reduction in the combined outcome of BPD and death was not affected by need for reintubation. ${ }^{123}$ The inflammatory response in the first few days of life is possibly different and less persistent, compared with later postnatal ages, and could potentially account for the improved pulmonary outcome. ${ }^{15124}$ A large multicenter retrospective study has shown that the total number of days of positive pressure delivered via an endotracheal tube is more predictive of adverse long term pulmonary outcomes than the number of courses of invasive mechanical ventilation. ${ }^{125}$ Earlier extubation was associated with reduced supplemental oxygen requirement at 36 weeks' PMA and shorter length of hospital stay in another retrospective study where the need for reintubation was also not shown to influence either mortality or incidence of BPD. ${ }^{126}$ However, another recent retrospective study showed a significant association between recommencement of invasive mechanical ventilation and the composite outcome of BPD or death. ${ }^{127}$ The relation between reintubation and death or moderate to severe BPD was strongest when invasive mechanical ventilation was 


\begin{tabular}{|c|c|c|c|c|c|c|c|c|}
\hline Study description & $\begin{array}{l}\text { Time on } \\
\text { respiratory } \\
\text { support }\end{array}$ & $\begin{array}{l}\text { BPD at } 36 \\
\text { weeks }\end{array}$ & $\begin{array}{l}\text { Death or BPD at } \\
36 \text { weeks' PMA }\end{array}$ & Home oxygen & Cerebral palsy & $\begin{array}{l}\text { Cerebral palsy } \\
\text { or death }\end{array}$ & $\begin{array}{l}\text { Late onset } \\
\text { sepsis }\end{array}$ & SIP \\
\hline $\begin{array}{l}\text { Meta-analysis of RCTs } \\
\text { using dexamethasone in } \\
\text { preterm infants }<8 \text { days } \\
\text { of life }^{135}\end{array}$ & $\begin{array}{l}\text { Failure to } \\
\text { extubate at } 7 \\
\text { days } 0.71(0.64- \\
0.84)\end{array}$ & $0.71(0.62-0.85)$ & $0.87(0.80-0.94)$ & $0.78(0.48-1.26)$ & $1.75(1.20-2.55)$ & $1.17(1.00-1.37)$ & $1.02(0.91-1.15)$ & $\begin{array}{l}\text { RD } 0.03(0.01- \\
0.05)\end{array}$ \\
\hline $\begin{array}{l}\text { GRADE: Moderate to } \\
\text { high }\end{array}$ & 6 RCTs, $n=703$ & 16 RCTs, $n=2584$ & 16 RCTs, $n=2581$ & 3 RCTs, $n=691$ & 7 RCTs, $n=921$ & 7 RCTs, $n=921$ & 14 RCTs, $n=2821$ & 9 RCTs, $n=1936$ \\
\hline $\begin{array}{l}\text { Meta-analysis of RCTs } \\
\text { using dexamethasone } \\
\text { in preterm infants }>7 \\
\text { days } \\
136\end{array}$ & $\begin{array}{l}\text { Failure to } \\
\text { extubate by day } \\
7 \text { of } R \times 0.65 \\
(0.59-0.72)\end{array}$ & $0.77(0.67-0.88)$ & $0.77(0.70-0.86)$ & $0.71(0.54-0.94)$ & $1.16(0.82-1.64)$ & $0.95(0.78-1.15)$ & $1.14(0.97-1.34)$ & $1.60(0.28-9.31)$ \\
\hline $\begin{array}{l}\text { GRADE: Moderate to } \\
\text { high }\end{array}$ & 15 RCTs, $n=761$ & 11 RCTs, $n=580$ & 11 RCTs, $n=580$ & 7 RCTs, $n=611$ & 16 RCTs, $\mathrm{n}=919$ & 16 RCTs, $\mathrm{n}=919$ & 18 RCTs, $\mathrm{n}=1349$ & 3 RCTs, $n=159$ \\
\hline $\begin{array}{l}\text { Single patient analysis } \\
\text { of RCTs using low dose } \\
\text { hydrocortisone in the } \\
\text { first week of life } \\
\text { Preterm infants mean GA } \\
25.2 \text { to } 26.9 \text { weeks }{ }^{137} \\
\text { GRADE: High }\end{array}$ & $\begin{array}{l}\text { No significant } \\
\text { difference in } \\
\text { number of days' } \\
\text { ventilation. } \\
\text { Extubation prior } \\
\text { to } 10 \text { days of life. } \\
2.07(1.42-3.02 \\
P=0.002) \text {. } \\
1 R T^{138} \\
n=522\end{array}$ & $\begin{array}{l}0.73(0.54-0.98 \\
P=0.038) \\
4 \text { RCTs } \\
n=982\end{array}$ & $\begin{array}{l}\text { Survival without } \\
\text { BPD } \\
1.45 \text { (1.11-1.90 } \\
P=0.007) \\
\geq 26 \text { weeks } 1.52 \\
(1.07-2.17) \\
\text { Chorio } \\
2.01(1.19-3.39 \\
P=0.009) \\
4 \text { RCTs } \\
n=982\end{array}$ & $\begin{array}{l}0.92 \\
(0.64-1.33) \\
4 \text { RCTs } \\
n=982\end{array}$ & $\begin{array}{l}0.95(0.56-1.60) \\
4 \text { RCTs } \\
n=709 \text { (came for } \\
\text { follow-up) }\end{array}$ & $N / R$ & $\begin{array}{l}1.34(1.02-1.75) \\
>26 \text { weeks } \\
1.14(0.78-1.65) \\
P=0.5 \\
\text { Chorio } \\
1.91 \\
(1.18-3.08 \\
P=0.009) \\
4 \text { RCTs } \\
n=982\end{array}$ & $\begin{array}{l}2.5(1.33-4.69 \\
P=0.004) \\
\text { No Indo } \\
1.52(0.73-3.15 \\
P=0.26) \\
4 \text { RCTs } \\
n=982\end{array}$ \\
\hline $\begin{array}{l}\text { RCT of hydrocortisone } \\
72.5 \mathrm{mg} / \mathrm{kg} / 22 \text { days in } \\
\text { PT infants dependent on } \\
\text { MV at } 7-14 \text { days }{ }^{139} \\
\text { GRADE: High }\end{array}$ & $\begin{array}{l}\text { Failure to } \\
\text { extubate by day } \\
7 \text { of } R x \\
0.34(0.21-0.54 \\
P<0.001)\end{array}$ & $1.24(0.82-1.86)$ & $0.87(0.54-1.38)$ & NR & NR & NR & $0.80(0.61-1.05)$ & $\begin{array}{l}\mathrm{RD}-2.5(-6.8- \\
1.5)\end{array}$ \\
\hline
\end{tabular}

recommenced within 48 hours of the first extubation attempt, a finding that maintained significance even when adjusted for total duration of invasive mechanical ventilation (OR 12.76, 95\% CI, 1.38 to 117.62). ${ }^{127}$ Interestingly, reintubation was not found to be associated with increased risk for moderate to severe BPD alone (OR 1.09, 95\% CI, 0.38 to 3.15).

In summary, current evidence continues to support the need for proactive weaning of invasive mechanical ventilation during the first week of life and consideration for a trial of extubation in infants who tolerate weaning to low settings, even if long term success is not guaranteed. ${ }^{126}$

\section{Caffeine}

Early initiation of caffeine therapy, within the first three days of life, has a significant impact in reducing $\mathrm{BPD}^{128} 129$ and associated long term neurological morbidity. ${ }^{130}$ An RCT showed that initiation of caffeine within 10 days of life significantly reduced the incidence of BPD (AOR 0.63, 96\% CI 0.53 to 0.76 , $\mathrm{P}<0.001) .^{90}$ Lung function studies performed on children aged 11 who had overcome BPD and were enrolled in the same study revealed a significant improvement in expiratory flow in those who received caffeine $\left(\mathrm{FEV}_{1}\right.$ : mean $\mathrm{Z}$ score; -1.0 versus 1.53; mean difference, $0.54,95 \%$ CI, 0.14 to 0.94 , $\mathrm{P}=0.008) .{ }^{131}$ Subgroup analysis of a trial, ${ }^{132}$ together with other studies ${ }^{133134}$ indicated that the greatest benefit was obtained by infants who receive caffeine within the first three days of life. Questions remain regarding the optimal dosage and timing of caffeine initiation to prevent or mitigate BPD. An RCT is under way to compare the effect of earlier ( 2 hours of life) with later (12 hours of life) initiation of caffeine (NCT03086473).

\section{Postnatal steroids}

The use of postnatal steroids for the prevention and mitigation of BPD remains a controversial topic (table 4). Early use of dexamethasone has been consistently associated with reduced duration of mechanical ventilation and a reduction in the outcome of BPD; this is at the cost of increased risk of NDI and cerebral palsy. ${ }^{135}$ Use of dexamethasone is therefore strongly discouraged in the first week of life. After the first week of life, treatment with postnatal glucocorticoids may reduce the incidence of NDI in infants at high risk for poor pulmonary outcomes. ${ }^{141}$ Administration of a low dose course of dexamethasone $(0.89 \mathrm{mg} / \mathrm{kg}$ over 10 days $)$ to infants on mechanical ventilation after one week of life was found to be associated with increased likelihood of extubation at the end of treatment (OR 11.2, 95\% CI 3.2 to 39.0 ) but not with reduced BPD. ${ }^{142}$ Follow-up did not find any adverse consequences or improvements in neurodevelopmental outcome. ${ }^{143}$ Postnatal dexamethasone should therefore continue to be reserved for the infants at highest risk of developing BPD who remain dependent on mechanical ventilation beyond 21 days of life. ${ }^{144}$

An individual patient meta-analysis of four RCTs (table 4) ${ }^{138}$ 145-147 showed treatment with low dose hydrocortisone to be associated with a significant 
increase in survival without BPD (OR 1.45, 95\% CI, 1.11 to $1.90, \mathrm{P}=0.007)$ and a decrease in the outcome of BPD (OR 0.73, 95\% CI, 0.54 to 0.98, $\mathrm{P}=0.38$ ). Subgroup analysis showed that BPDfree survival was enhanced in infants exposed to chorioamnionitis but failed to reach significance for infants with gestational age $<26$ weeks. An RCT that evaluated the later use of hydrocortisone at a higher dose in infants who remained dependent on mechanical ventilation did not show any improvement in the outcome of $\mathrm{BPD} .{ }^{139}$ In contrast with the early use of dexamethasone, early low dose hydrocortisone has not been associated with increased risk of neurosensory impairment. ${ }^{148}$ In summary, treatment with low dose hydrocortisone in the first week of life, but not a later or higher dose, is associated with a small but significant improvement in the diagnosis of BPD, especially in infants exposed to chorioamnionitis. ${ }^{137} 149$ Long term pulmonary benefits resulting from a reduction in the outcome of BPD are yet to be determined.

Regarding early inhaled budesonide, in an RCT with 437 infants given budesonide versus 417 given a placebo, in reducing the outcome of BPD (RR $0.74,95 \%$ CI 0.60 to $0.91, \mathrm{P}=0.004)$, the composite outcome of death or BPD was partially offset by a non-statistically significant trend towards increased mortality in the intervention group (RR 1.24, 95\% CI 0.91 to $1.69, \mathrm{P}=0.17){ }^{150}$ The 2 year outcomes of the study revealed that the early trend towards increased mortality in the intervention group reached significance (RR 1.37, 95\% CI, 1.01 to1.86, $\mathrm{P}=0.04)^{151}$ For this reason, early use of inhaled budesonide is not recommended to prevent BPD.

\section{Diuretic therapy}

Chronic, mild pulmonary edema was included in the initial description of the "New BPD" phenotype and both loop and thiazide diuretics continue to be commonly used in preterm infants with evolving and established BPD. ${ }^{152} 153$ Diuretic use is more common in extremely preterm infants who are on higher levels of respiratory support ${ }^{154155}$ and the relation between initiation of therapy and improvement in respiratory status has been inconsistent. ${ }^{154} 156$ Although a significant association between increased duration of furosemide exposure and reduced incidence of BPD was noted in a large multicenter retrospective cohort study, ${ }^{155}$ given the study design, it is not possible to infer causality. As furosemide therapy is linked with multiple adverse consequences, ${ }^{157}$ including reduced weight gain, electrolyte losses, nephrocalcinosis, ${ }^{158}$ and metabolic bone disease ${ }^{159}$; diuretics should be used judiciously in preterm infants with treatment limited to those that show clinical improvement.

\section{Inhaled bronchodilators}

The phenotype of BPD is associated with hypertrophy of the smooth muscle surrounding the airways and inflammation. ${ }^{160}$ The fixed and reversible component to airway hyper-reactivity in preterm infants may be more pronounced in those with BPD, as noted by consistently reduced spirometry values. ${ }^{49} \mathrm{~A}$ systematic review and meta-analysis measuring bronchial hyper-responsiveness (BHR) in adults and children born preterm with and without $B P D$ revealed that the risk of BHR was increased in participants with BPD for both methacholine challenge (OR 2.59, 95\% CI, 1.50 to 4.50) and exercise challenge (OR 5.13, 95\% CI, 1.82 to 14.47$)$. To date there is no evidence linking inhaled steroids and bronchodilators with either reduction in BPD or mortality. ${ }^{161}$ The ERS advises the use of bronchodilators only in infants with severe BPD who have asthma-like symptoms (dry cough/wheezing), exercise induced symptoms, frequent hospital admissions, and show reversibility on testing. ${ }^{57}$

\section{Nutritional strategies}

The ability to maintain lung growth and repair is dependent on adequate postnatal nutrition. A retrospective cohort study revealed that both lower energy intake during the first four weeks of life and increased fluid intake were significantly associated with BPD. ${ }^{162}$ Relative fluid restriction, early introduction of enteral feedings, and optimization of parenteral nutrition components should be strongly considered. An RCT revealed a significant reduction in BPD in infants given donor milk relative to the formula supplemented group (15\% versus $28 \%$, $\mathrm{P}=0.048){ }^{163}$ Exclusive feeding with fresh maternal breast milk was significantly associated with a decrease in BPD (OR 0.40, 95\% CI, 0.27 to 0.67, $\mathrm{P}<0.001){ }^{164}$ Maintenance of an exclusive human milk diet, ideally the use of fresh maternal breast milk, is recommended in the management of infants with early and evolving BPD.

\section{Management-established BPD}

If there is concern for BPD-PH, ${ }^{165} \mathrm{SpO}_{2}$ targets are usually $\sim 95 \%$ (ranging from $92 \%$ to $98 \%$ ). ${ }^{12}$ Additional agents may be required, but description of the management of BPD-PH is beyond the scope of this review.

Ventilator management for the subset of infants with severe BPD is especially challenging, with limited high quality data available to guide the clinician. ${ }^{166}$ The two major phenotypes of severe BPD are predominantly atelectatic or cystic. ${ }^{166} 167$ In the former type, higher positive end expiratory pressures (PEEP), up to $12 \mathrm{~cm} \mathrm{H}_{2} \mathrm{O}$ may be required, with tidal volumes of 4-7 mL/kg. In the cystic type, moderate PEEPs of 4-8 $\mathrm{cm} \mathrm{H}_{2} \mathrm{O}$ with higher tidal volumes of 10$12 \mathrm{~mL} / \mathrm{kg}$ are required to provide optimal oxygenation and ventilation. ${ }^{166} 167$ For infants still requiring invasive ventilation at 90-100 days of life, with $>5-7$ failed attempts at extubation, a tracheostomy should be considered. ${ }^{168}$ Tracheostomy has been associated with improved growth and development. ${ }^{169}$ Information about long term ventilation in babies with established BPD are available, ${ }^{170} 171$ although beyond the scope of this review. In patients with established oxygen dependent BPD, the use of prednisolone was successful in weaning 
supplemental oxygen. ${ }^{172}$ Diuretics are continued, as in the early and evolving phases of BPD. ${ }^{12}$ More evidence based data are required to guide diuretic therapy in established BPD. ${ }^{173}$ Use of beta-agonists, with or without anticholinergics, may be employed in infants with BHR. ${ }^{12}$

Recommendations for initiation and weaning home oxygen support are shown in table 5. ${ }^{167} 174$ Infants often receive chronic diuretic therapy despite scarce data to support this practice or guidelines to discontinue them, post-discharge from the NICU. ${ }^{175}$ A subset of patients will continue to receive inhaled steroids and bronchodilator therapy post discharge. ${ }^{175}$

\section{Guidelines for management of BPD}

Table 6 summarizes recommendations for the clinical management of infants with early, evolving, and established BPD. Many of these recommendations are our own, based on evidence from the literature; however, we have included several recommendations by the ERS. ${ }^{57}$ The recommendation to target $\mathrm{SpO}_{2}$ for infants discharged on supplemental oxygen is in agreement with guidance issued from the American Academy of Pediatrics (AAP) Committee of the Fetus and Newborn (COFN) and ERS. ${ }^{188} 189$ The ERS and AAP COFN advocate early use of CPAP in respiratory distress syndrome, early administration of caffeine, and selective administration of surfactant. ${ }^{189190}$ For invasive mechanical ventilation, a volume targeted approach is recommended. ${ }^{189}$ ERS and AAP COFN guidelines differ in the technique recommended for surfactant delivery. Current ERS guidelines advocate less invasive surfactant administration (LISA) whereby surfactant is delivered during spontaneous breathing via a semi-rigid catheter or a feeding tube placed in the airway. In contrast, the AAP COFN guidelines recommend consideration for delivery using the intubation surfactant administration and rapid extubation technique (InSURE). AAP COFN guidelines, however, do not reflect some of the more recent evidence emerging regarding the potential advantages of LISA that have emerged in the past seven years. ${ }^{104}$

The American Thoracic Society (ATS), American Heart Association (AHA), and EPPVDN recommend that infants with established BPD should undergo screening for BPD-PH. ${ }^{40} 191$ The lack of an international consensus guideline on the diagnosis of BPD is a major obstacle to progress in clinical research and should be an important focus for future collaboration. $^{30}$

\section{Emerging treatments}

As research continues to highlight the critical role played by intrauterine exposures in the development of BPD and BPD-PH, interventions that occur in the antenatal period may have the potential to offer protection. Maternal smoking is an important risk factor for persistent respiratory disease in preterm infants. ${ }^{192}$ RCT evidence shows that antenatal vitamin C supplementation is associated with improved pulmonary function tests and reduced incidence of wheezing during infancy in newborns whose mothers smoked tobacco during pregnancy. ${ }^{193}$ No evidence suggests that antenatal vitamin C supplementation is of benefit in preventing BPD.

Intrauterine infection and inflammation have also been strongly implicated in the development of BPD. ${ }^{15}$ A phase I placebo controlled RCT of N-acetylcysteine

\begin{tabular}{|c|c|}
\hline \multicolumn{2}{|c|}{ Criteria for home use of oxygen: initiation } \\
\hline \multicolumn{2}{|c|}{ Postmenstrual age at least 36 weeks } \\
\hline Medical problems & Absence of apnea; stabilized or regressed ROP \\
\hline Growth & Weight gain of at least $20 \mathrm{~g} /$ day \\
\hline Immunization & Completed as appropriate for postnatal age; received first dose of RSV prophylaxis, if appropriate \\
\hline Flow rate & Stable for at least 1 week on flow rate of $1-2 \mathrm{~L} / \mathrm{min} \mathrm{FiO}_{2} 1.0$, and maintaining saturations $\geq 92 \%$ \\
\hline Home monitoring & Availability of continuous $\mathrm{SpO}_{2}$ monitoring and downloading data capability \\
\hline Home environment & Adequate caregiver teaching and home supplies \\
\hline \multicolumn{2}{|c|}{ Criteria for home oxygen use: weaning } \\
\hline Follow-up & Every 4 weeks, or sooner, if needed \\
\hline \multirow[t]{4}{*}{ Weaning process } & $\begin{array}{l}\text { Wean flow } 1 / 4 \text { to } 1 / 8 \text { LPM or } 0.25 \text { to } 0.1 \text { LPM } \\
\text { Increase flow if } \mathrm{SpO}_{2}<93 \% \\
\text { Target } \mathrm{SpO}_{2} \geq 92-96 \% \\
\text { Consider a slower wean if BPD-PH is present } \\
\text { Consider not weaning if growth is inadequate } \\
\text { Wean to room air when awake, first, then: }\end{array}$ \\
\hline & $\begin{array}{l}\text { Overnight oximetry test } \\
\text { If } \mathrm{SpO}_{2}>90 \% \text { for } 98 \% \text { time of the study, wean to room air. } \\
\text { Can consider weaning to room air if } \mathrm{SpO}_{2}>90 \% \text { for } 96 \% \text { time of the study with no low saturation values and absence of artifacts, except when other } \\
\text { co-morbidities exist (BPD-PH, inadequate growth) } \\
\text { Repeat oximetry in room air }\end{array}$ \\
\hline & $\begin{array}{l}\text { Overnight polysomnography } \\
\text { Discontinue } \mathrm{O}_{2} \text { if there is less than } 20 \text { minutes } \mathrm{SpO}_{2}<92 \% \text {, no continuous desaturation } \measuredangle 92 \% \text { for more than } 5 \text { minutes or only infrequent desaturations } \\
\text { of } 4 \% \text { causing arousal without evidence of obstruction }\end{array}$ \\
\hline & $\begin{array}{l}\text { Stable in room air } \\
\text { Keep } \mathrm{O}_{2} \text { cylinder and pulse oximeter at home for use as needed for at least } 3 \text { months to allow for acute deteriorations, eg, URIs }\end{array}$ \\
\hline $\mathrm{fs}^{1671}$ & BPD-PH=bronchopulmonary dysplasia-pulmonary hypertension; $\mathrm{LPM}=$ liters per minute; $R O P=$ retinopathy of prematurity; $R S V=$ respiratory sync \\
\hline
\end{tabular}




\begin{tabular}{|c|c|c|c|}
\hline Therapeutic intervention & Current status & Evidence level & Recommendation level \\
\hline \multicolumn{4}{|c|}{ Early phase (up to 1 postnatal week) } \\
\hline \multirow[t]{3}{*}{ Oxygen supplementation } & Resuscitation: & & \\
\hline & Titrate supplemental oxygen to obtain preductal oxygen saturation $>80 \%$ by 5 minutes of life $\mathrm{e}^{93}$ & I & B \\
\hline & Maintain oxygen saturations $90-95 \%^{96}$ & I & A \\
\hline \multirow[t]{6}{*}{ Ventilatory strategy } & Trial of CPAP for spontaneously breathing infants & I & A \\
\hline & 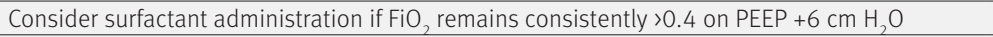 & I & B \\
\hline & Use InSURE/LISA technique to administer surfactant & I & B \\
\hline & Consider volume targeted ventilation strategies: TV 4-6 mL/ $\mathrm{kg}^{119}$ & I & A \\
\hline & $\begin{array}{l}\text { Use short inspiratory times }(0.3-0.4 \mathrm{~S}),{ }^{177} \text { rapid rates }(40-60 \text { per min) and low PIP on pressure } \\
\text { control settings }\left(14-20 \mathrm{~cm} \mathrm{H}_{2} \mathrm{O}\right) \text {, moderate PEEP }\left(4-6 \mathrm{~cm} \mathrm{H}_{2} \mathrm{O}\right){ }^{178} \mathrm{PaO}_{2}: 40-60 \mathrm{~mm} \mathrm{Hg} ; \mathrm{PaCO}_{2} \\
: 45-55 \mathrm{~mm} \mathrm{Hg}{ }^{179}\end{array}$ & III & B \\
\hline & $\begin{array}{l}\text { Trial of extubation to NIPPV/SNIPPV prior to } 7 \text { days in infants who tolerate weaning to minimal } \\
\text { settings }{ }^{180}\end{array}$ & $11-2$ & B \\
\hline Methylxanthines & Administration of caffeine within first 3 days of life decreases BPD ${ }^{128} 132$ & I & A \\
\hline $\begin{array}{l}\text { Intratracheal administration of } \\
\text { budesonide and surfactant }\end{array}$ & $\begin{array}{l}\text { Associated with an increase in BPD free survival (NNT } 4.1 \text { [95\% Cl } 2.8 \text { to } 7.8]]^{181} \\
\text { Studies to date not adequately powered to assess long term neurodevelopmental outcome }\end{array}$ & I & B \\
\hline Vitamin A & $\begin{array}{l}\text { Improves BPD free survival with reported NNT 14-15 }{ }^{182} \text { Dose: } 5000 \text { IU given intramuscularly } 3 \\
\text { times a week for } 4 \text { weeks }\end{array}$ & I & A \\
\hline Low dose hydrocortisone & $\begin{array}{l}\text { Low dose hydrocortisone (total dose } 8.5 \mathrm{mg} \text { over } 10 \text { days) is associated with increased BPD } \\
\text { free survival } \\
\text { Increased risk of late onset sepsis in infants }<26 \text { weeks }^{137} \\
\text { Increased risk of SIP in infants who receive indomethacin }{ }^{137}\end{array}$ & I & C \\
\hline Fluids & Restrictive fluid intake may decrease BPD ${ }^{183}$ & $11-2$ & B \\
\hline \multirow[t]{2}{*}{ Nutrition } & Exclusive human milk feeding reduces the risk for BPD ${ }^{163}$ & I & A \\
\hline & Provide increased energy intake ${ }^{162}$ & $11-2$ & A \\
\hline \multicolumn{4}{|c|}{ Evolving BPD (> 1 postnatal week to 36 weeks' PMA) } \\
\hline \multirow[t]{2}{*}{ Dexamethasone } & $\begin{array}{l}\text { Low dose dexamethasone ( } 0.89 \mathrm{mg} / \mathrm{kg} \text { over } 10 \text { days) facilitates extubation but does not } \\
\text { reduce BPD }{ }^{142}\end{array}$ & I & C \\
\hline & $\begin{array}{l}\text { High dose dexamethasone }(0.5 \mathrm{mg} / \mathrm{kg}-1 \mathrm{mg} / \mathrm{kg} \text { ) reduces BPD but may increase the risk of NDI } \\
\text { and } \mathrm{CP}^{184} \\
\text { Greatest global benefit is for infants with risk of BPD }>66 \% \text {-ie, those who remain intubated at } \\
3-4 \text { weeks postnatal age } 141185\end{array}$ & I & C \\
\hline \multirow[t]{2}{*}{ Ventilatory strategy } & $\begin{array}{l}\text { Avoid endotracheal tube ventilation, encourage non-invasive support strategies (NIPPV, } \\
\text { SNIPPV, nCPAP }{ }^{18} 0\end{array}$ & I & A \\
\hline & $\begin{array}{l}\text { Blood gas targets: } \mathrm{pH} 7.25-7.35 ; \mathrm{PaO}_{2} 50-70 \mathrm{~mm} \mathrm{Hg} ; \mathrm{PCO}_{2} 50-60 \mathrm{~mm} \mathrm{Hg}^{179} \\
\text { No advantage to allowing higher } \mathrm{CO}_{2} \text { limit }^{186}\end{array}$ & I & A \\
\hline Diuretics & $\begin{array}{l}\text { May improve respiratory mechanics and facilitate weaning of support. Do not prevent BPD. } \\
\text { Continue use only if clear response demonstrated }\end{array}$ & I & B \\
\hline Nutrition & Same as for early phase & I & A \\
\hline Methylxanthines & Same as for early phase & I & A \\
\hline \multicolumn{4}{|c|}{ Established phase ( $>36$ weeks’ PMA) } \\
\hline $\begin{array}{l}\text { Echocardiographic screening for } \\
\text { BPD PH }\end{array}$ & $\begin{array}{l}25 \% \text { of infants with moderate or severe BPD have echocardiographic evidence of pulmonary } \\
\text { hypertension }{ }^{40}\end{array}$ & III & A \\
\hline Bronchodilators & May improve symptoms in subpopulations of affected infants ${ }^{57}$ & $11-3$ & B \\
\hline Inhaled steroids & Later use may improve symptoms in subpopulations of infants ${ }^{57}$ & III & B \\
\hline \multirow[t]{2}{*}{ Diuretics } & Chronic therapy as for the evolving phase ${ }^{37}$ & I & B \\
\hline & Consider allowing infant to outgrow dose $\mathrm{s}^{57}$ & III & $\mathrm{B}$ \\
\hline Nutrition & Same as for early and evolving phase. Avoid excessive weight gain & $11-2$ & A \\
\hline Immunization & $\begin{array}{l}\text { Prophylaxis against RSV and influenza decreases re-hospitalization and morbidity } \\
\text { RSV prophylaxis is cost effective }{ }^{187}\end{array}$ & । & A \\
\hline
\end{tabular}

administration in women presenting in preterm labor with confirmed intrauterine infection or inflammation showed a dramatic reduction in the incidence of BPD in infants born to mothers in the treatment group (RR $0.1,95 \% \mathrm{CI}, 0.01$ to 0.73 ). Data from a larger scale RCT are required before this approach is incorporated into clinical practice.

Use of exogenous surfactant as a medium to deliver budesonide directly to the airspaces has shown promise in reducing the outcome of BPD. ${ }^{181} 194$ In an RCT, the effects of a preparation of $0.25 \mathrm{mg} / \mathrm{kg}$ budesonide combined with $100 \mathrm{mg} / \mathrm{kg}$ surfactant (Survanta, Abbott Laboratories, Abbott Park, IL) was compared with $100 \mathrm{mg} / \mathrm{kg}$ surfactant alone, in a group of 265 intubated VLBW infants. ${ }^{181}$ The primary outcome of death or BPD was significantly reduced in the interventional group $(42 \%$ versus 66\%, RR 0.58, $95 \%$ CI 0.44 to 0.77 , P<0.001, NNT 4.1). The incidence of BPD was reduced in the intervention group (29\% versus 50\%, RR 0.70, $95 \%$ CI 0.58 to $0.86, \mathrm{P}<0.001)$ without significant increase in mortality. A meta-analysis ${ }^{195}$ reported a $43 \%$ reduction in the risk for BPD in the intervention group (RR 0.57, 95\% CI, 0.43 to 0.76 , NNT 5) with a decrease in the combined outcome of BPD or death (RR $0.60,95 \%$ CI, 0.49 to 0.74 , NNT 3). The budesonide 
in babies trial (NCT04545866) has been designed to evaluate the pulmonary and neurodevelopmental outcomes of infants of $22-28^{+6}$ gestational age who receive a combination of $0.25 \mathrm{mg} / \mathrm{kg}$ budesonide and $2.5 \mathrm{~mL} / \mathrm{kg}$ surfactant with those who had $2.5 \mathrm{~mL} / \mathrm{kg}$ surfactant alone. This trial is currently recruiting and likely to report in 5-6 years' time.

Deficiencies in insulin-like growth factor 1 (IGF-1) have been shown to be linked to the pathogenesis of BPD. ${ }^{196}$ A phase II clinical trial designed to evaluate the safety and efficacy of recombinant human IGF1 complexed with its binding protein (rhIGF-1/ rhIGFBP-3) in the prevention of retinopathy of prematurity noted a statistically significant decrease in the incidence of BPD in the 61 infants who received the treatment (21.3\% treated versus $44.9 \%$ standard care; $\mathrm{P}=0.04) .{ }^{197}$ This effect was even more pronounced in the 24 infants in whom IGF-1 levels in the target range were reached $(4.8 \%$ treated versus $44.9 \%$ standard care; $\mathrm{P}=0.02) .{ }^{197}$ A large placebo controlled RCT designed to evaluate the benefit of rhIGF-1/rhIGFBP-3 is ongoing (NCT03253263) and likely to report in 5-6 years' time.

Mesenchymal stem cell (MSC) based therapies have shown great potential for the management of a range of different neonatal conditions including BPD. ${ }^{198}$ Findings from a phase II RCT investigating the effect of intratracheal administration of MSCs to preterm infants of 23-28 weeks' gestational age showed a reduction in the incidence of severe BPD in a subgroup of infants born at 23-24 weeks' gestational age (19\% treatment group [3/16] versus $53 \%$ placebo group [8/15]). ${ }^{199}$ A larger multicenter phase II trial focusing on the use of intratracheally delivered MSCs in infants of 23-25 weeks' gestational age is under way (NCT03392467). A clinical trial evaluating the safety of intravenously administered bone marrow MSC derived extracellular vesicles in preterm infants of 23-26 weeks' gestational age is also in progress (NCT03857841).

\section{Conclusions}

BPD is a complex multifactorial lung condition that is also associated with other pathologies that affect preterm infants such as NDI and growth failure. The lack of an objective definition of BPD poses a significant challenge to the evaluation of new treatments. ${ }^{200}$ The Shennan 1988 definition $^{29}$ remains the most consistently used criterion to define BPD in clinical studies. ${ }^{30}$ The NIH 2001 outcome of severe BPD, known to be associated with significantly increased morbidity and mortality, ${ }^{31}$ is frequently not reported. The NIH 2018 definition is yet to be validated in a large neonatal population. As work continues in the development of more objective criteria defined by biomarkers or "omic" technology, the consistent use of clinical definitions with the potential to differentiate subjects with the highest risk for mortality and morbidity should remain a strong consideration. Despite advances in the understanding of the pathogenesis of BPD, relatively few of the treatments available are supported by

\section{QUESTIONS FOR FUTURE RESEARCH}

- How accurate is the 2018 NHLBI definition of BPD in predicting long term mortality and morbidity?

- How can biomarkers and "omic" approaches be best utilized for the early prediction of BPD and definition of specific phenotypes?

- Is the use of intratracheal budesonide associated with improved long term pulmonary outcome? Are there any risks of NDI?

- What is the utility of LISA in reducing the incidence of BPD and improving long term outcomes? Could there be added benefit to combining LISA with intratracheal budesonide?

- How can we optimize the management of infants with severe BPD and BPD-PH?

high quality evidence. Novel therapies to prevent or mitigate the severity of BPD therefore have the potential to transform healthcare outcomes for a growing population of survivors of prematurity.

Competing interests: The authors have nothing to disclose Contributorship statement and guarantor: MG, $A B$, and VB made substantial contributions to the concept of the manuscript. MG, $A B$, and VB made substantial contributions to the interpretation of published literature for the manuscript. MG produced the initial draft of the manuscript. $A B$ and $V B$ revised the manuscript critically for important intellectual content. MG, $A B$, and $V B$ gave final approval of the manuscript. VB is guarantor for all aspects of the manuscript in ensuring that questions related to the accuracy or integrity of any part of the work are appropriately investigated and resolved.

No patients were directly involved in the creation of this article. Provenance and peer review: commissioned; externally peer reviewed.

1 Thébaud B, Goss KN, Laughon M, et al. Bronchopulmonary dysplasia. Nat Rev Dis Primers 2019;5:78. doi:10.1038/s41572-019-0127-7

2 Stoll BJ, Hansen NI, Bell EF, et al, Eunice Kennedy Shriver National Institute of Child Health and Human Development Neonatal Research Network. Trends in care practices, morbidity, and mortality of extremely preterm neonates, 1993-2012. JAMA 2015;314:1039-51. doi:10.1001/jama.2015.10244

3 Lui K, Lee SK, Kusuda S, et al, International Network for Evaluation of Outcomes (iNeo) of neonates Investigators. Trends in outcomes for neonates born very preterm and very low birth weight in 11 highincome countries. J Pediatr 2019;215:32-40.e14. doi:10.1016/j. jpeds.2019.08.020

4 Bhandari A, Panitch HB. Pulmonary outcomes in bronchopulmonary dysplasia. Semin Perinatol 2006;30:219-26. doi:10.1053/j. semperi.2006.05.009

5 Davidson LM, Berkelhamer SK. Bronchopulmonary dysplasia: chronic lung disease of infancy and long-term pulmonary outcomes. J Clin Med 2017;6:4. doi:10.3390/jcm6010004

6 Álvarez-Fuente M, Arruza L, Muro M, et al. The economic impact of prematurity and bronchopulmonary dysplasia. Eur J Pediatr 2017;176:1587-93. doi:10.1007/s00431-017-3009-6 van Katwyk S, Augustine S, Thébaud B, Thavorn K. Lifetime patient outcomes and healthcare utilization for Bronchopulmonary dysplasia (BPD) and extreme preterm infants: a microsimulation study. BMC Pediatr 2020;20:136. doi:10.1186/s12887-020-02037-5

8 Steinhorn R, Davis JM, Göpel W, et al, International Neonatal Consortium. Chronic pulmonary insufficiency of prematurity: developing optimal endpoints for drug development. J Pediatr 2017:191:15-21.e1. doi:10.1016/j.jpeds.2017.08.006

9 Wang SH, Tsao PN. Phenotypes of bronchopulmonary dysplasia. Int J Mol Sci 2020;21:6112. doi:10.3390/ijms21176112

10 Jobe AH, Bancalari E. Bronchopulmonary dysplasia. Am J Respir Crit Care Med 2001;163:1723-9. doi:10.1164/ajrccm.163.7.2011060

11 Higgins RD, Jobe AH, Koso-Thomas M, et al. Bronchopulmonary dysplasia: executive summary of a workshop. J Pediatr 2018;197:300-8. doi:10.1016/j.jpeds.2018.01.043

12 Bhandari A, Bhandari V. Pitfalls, problems, and progress in bronchopulmonary dysplasia. Pediatrics 2009;123:1562-73. doi:10.1542/peds.2008-1962 
13 Northway WHJr, Rosan RC, Porter DY. Pulmonary disease following respirator therapy of hyaline-membrane disease. Bronchopulmonary dysplasia. N Engl J Med 1967;276:357-68. doi:10.1056/ NEJM196702162760701

14 Sahni M, Bhandari V. Recent advances in understanding and management of bronchopulmonary dysplasia. F1000Res 2020;9:F1000. doi:10.12688/f1000research.25338.1

15 Balany J, Bhandari V. Understanding the impact of infection, inflammation, and their persistence in the pathogenesis of bronchopulmonary dysplasia. Front Med (Lausanne) 2015;2:90. doi:10.3389/fmed.2015.00090

16 Yallapragada SG, Mestan KK, Palac H, et al. Placental villous vascularity is decreased in premature infants with bronchopulmonary dysplasia-associated pulmonary hypertension. Pediatr Dev Pathol 2016;19:101-7. doi:10.2350/15-05-1646-0A.1

17 Watterberg KL, American Academy of Pediatrics. Committee on Fetus and Newborn. Policy statement--postnatal corticosteroids to prevent or treat bronchopulmonary dysplasia. Pediatrics 2010;126:800-8. doi:10.1542/peds.2010-1534

18 Bhandari V, Gruen JR. The genetics of bronchopulmonary dysplasia. Semin Perinatol 2006;30:185-91. doi:10.1053/j. semperi.2006.05.005

19 Lal CV, Olave N, Travers C, et al. Exosomal microRNA predicts and protects against severe bronchopulmonary dysplasia in extremely premature infants. JCl Insight 2018;3:e93994. doi:10.1172/jci. insight.93994

20 Broughton S, Bhat R, Roberts A, Zuckerman M, Rafferty G, Greenough A. Diminished lung function, RSV infection, and respiratory morbidity in prematurely born infants. Arch Dis Child 2006;91:26-30. doi:10.1136/adc.2005.087270

21 Saugstad OD, Sejersted Y, Solberg R, Wollen EJ, Bjørås M. Oxygenation of the newborn: a molecular approach. Neonatology 2012;101:315 25. doi:10.1159/000337345

22 Keszler M, Sant'Anna G. Mechanical ventilation and bronchopulmonary dysplasia. Clin Perinatol 2015;42:781-96. doi:10.1016/i.clp.2015.08.006

23 Bamat NA, Kirpalani H, Feudtner C, et al. Medication use in infants with severe bronchopulmonary dysplasia admitted to United States children's hospitals. J Perinatol 2019;39:1291-9. doi:10.1038/ s41372-019-0415-9

24 Piersigilli F, Van Grambezen B, Hocq C, Danhaive O. Nutrients and microbiota in lung diseases of prematurity: the placenta-gut-lung triangle. Nutrients 2020:12:469. doi:10.3390/nu12020469

25 Wu KY, Jensen EA, White AM, et al. Characterization of disease phenotype in very preterm infants with severe bronchopulmonary dysplasia. Am / Respir Crit Care Med 2020;201:1398-406. doi:10.1164/rccm.201907-13420C

26 Hysinger EB, Friedman NL, Padula MA, et al, Children's Hospitals Neonatal Consortium. Tracheobronchomalacia is associated with increased morbidity in bronchopulmonary dysplasia. Ann Am Thorac Soc 2017; 14:1428-35. doi:10.1513/AnnalsATS.201702-1780C

27 Lagatta JM, Hysinger EB, Zaniletti I, et al, Children's Hospital Neonatal Consortium Severe BPD Focus Group. The impact of pulmonary hypertension in preterm infants with severe bronchopulmonary dysplasia through 1 year. J Pediatr 2018;203:218-224.e3. doi:10.1016/j.jpeds.2018.07.035

28 Tooley WH. Epidemiology of bronchopulmonary dysplasia. Pediatr 1979;95:851-8. doi:10.1016/S0022-3476(79)80451-5

29 Shennan AT, Dunn MS, Ohlsson A, Lennox K, Hoskins EM. Abnormal pulmonary outcomes in premature infants: prediction from oxygen requirement in the neonatal period. Pediatrics 1988;82:527-32

30 Hines D, Modi N, Lee SK, et al, International Network for Evaluating Outcomes (iNeo) of Neonates. Scoping review shows wide variation in the definitions of bronchopulmonary dysplasia in preterm infants and calls for a consensus. Acta Paediatr 2017:106:366-74. doi:10.1111/apa.13672

31 Ehrenkranz RA, Walsh MC, Vohr BR, et al, National Institutes of Child Health and Human Development Neonatal Research Network. Validation of the National Institutes of Health consensus definition of bronchopulmonary dysplasia. Pediatrics 2005;116:1353-60. doi:10.1542/peds.2005-0249

32 Poindexter BB, Feng R, Schmidt B, et al, Prematurity and Respiratory Outcomes Program. Comparisons and limitations of current definitions of bronchopulmonary dysplasia for the prematurity and respiratory outcomes program. Ann Am Thorac Soc 2015;12:1822 30. doi:10.1513/AnnalsATS.201504-2180C

33 Gomez Pomar E, Concina VA, Samide A, Westgate PM, Bada HS. Bronchopulmonary dysplasia: comparison between the two most used diagnostic criteria. Front Pediatr 2018:6:397 doi:10.3389/ fped.2018.00397

34 Malavolti AM, Bassler D, Arlettaz-Mieth R, Faldella G, Latal B, Natalucci G. Bronchopulmonary dysplasia-impact of severity and timing of diagnosis on neurodevelopment of preterm infants: a retrospective cohort study. BMJ Paediatr Open 2018;2:e000165. doi:10.1136/bmipo-2017-000165

35 Kim F, Bateman DA, Goldshtrom N, Sahni R, Wung JT, Wallman-Stokes A. Revisiting the definition of bronchopulmonary dysplasia in premature infants at a single center quaternary neonatal intensive care unit. Perinatol 2021:41:756-63 doi:10.1038/s41372-021-00980-4

36 Stoecklin B, Simpson SJ, Pillow JJ. Bronchopulmonary dysplasia: Rationale for a pathophysiological rather than treatment based approach to diagnosis. Paediatr Respir Rev 2019;32:91-7.

37 Stewart A, Brion LP, Ambrosio-Perez I. Diuretics acting on the distal renal tubule for preterm infants with (or developing) chronic lung disease. Cochrane Database Syst Rev 2011;9:CD001817. doi:10.1002/14651858.CD001817.pub2

38 Khalaf MN, Hurley JF, Bhandari V. A prospective controlled trial of albuterol aerosol delivered via metered dose inhaler-spacer device (MDI) versus jet nebulizer in ventilated preterm neonates. Am J Perinatol 2001;18:169-74. doi:10.1055/s-2001-14526

39 Slaughter JL, Stenger MR, Reagan PB. Variation in the use of diuretic therapy for infants with bronchopulmonary dysplasia. Pediatrics 2013;131:716-23. doi:10.1542/peds.2012-1835

40 Hansmann G, Koestenberger M, Alastalo TP, et al. 2019 updated consensus statement on the diagnosis and treatment of pediatric pulmonary hypertension: The European Pediatric Pulmonary Vascular Disease Network (EPPVDN), endorsed by AEPC, ESPR and ISHLT. J Heart Lung Transplant 2019;38:879-901. doi:10.1016/j. healun.2019.06.022

41 Mourani PM, Sontag MK, Younoszai A, et al. Early pulmonary vascular disease in preterm infants at risk for bronchopulmonary dysplasia. Am J Respir Crit Care Med 2015;191:87-95. doi:10.1164/ rccm.201409-15940C

42 Collaco JM, McGrath-Morrow SA. Respiratory phenotypes for preterm infants, children, and adults: bronchopulmonary dysplasia and more. Ann Am Thorac Soc 2018:15:530-8, doi:10.1513/ AnnalsATS.201709-756FR

43 Jensen EA, Dysart K, Gantz MG, et al. The diagnosis of bronchopulmonary dysplasia in very preterm infants. An evidencebased approach. Am J Respir Crit Care Med 2019;200:751-9. doi:10.1164/rccm.201812-23480C

44 Van Marter LI, Kuban KC, Allred E, et al, ELGAN Study Investigators. Does bronchopulmonary dysplasia contribute to the occurrence of cerebral palsy among infants born before 28 weeks of gestation?Arch Dis Child Fetal Neonatal Ed 2011;96:F20-9. doi:10.1136/ adc.2010.183012

45 Isayama T, Lee SK, Yang J, et al Canadian Neonatal Network and Canadian Neonatal Follow-Up Network Investigators. Revisiting the definition of bronchopulmonary dysplasia: effect of changing panoply of respiratory support for preterm neonates. JAMA Pediatr 2017;171:271-9. doi:10.1001/jamapediatrics.2016.4141

46 Walsh MC Yao Q Gettner P et al, National Institute of Child Health and Human Development Neonatal Research Network. Impact of a physiologic definition on bronchopulmonary dysplasia rates. Pediatrics 2004;114:1305-11. doi:10.1542/peds.2004-0204

47 Svedenkrans J, Stoecklin B, Jones JG, Doherty DA, Pillow JJ. Physiology and predictors of impaired gas exchange in infants with bronchopulmonary dysplasia. Am J Respir Crit Care Med 2019:200:471-80. doi:10.1164/rccm.201810-20370C

48 Coste F, Ferkol T, Hamvas A, et al. Ventilatory control and supplemental oxygen in premature infants with apparent chronic lung disease. Arch Dis Child Fetal Neonatal Ed 2015;100:F233-7. doi:10.1136/archdischild-2014-307272

49 Gibbons JTD, Wilson AC, Simpson SJ. Predicting lung health trajectories for survivors of preterm birth. Front Pediatr 2020;8:318. doi:10.3389/fped.2020.00318

50 Greenough A, Pahuja A. Updates on functional characterization of bronchopulmonary dysplasia-the contribution of lung function testing. Front Med (Lausanne) 2015;2:35. doi:10.3389/ fmed.2015.00035

51 Cazzato S, Ridolfi L, Bernardi F, Faldella G, Bertelli L. Lung function outcome at school age in very low birth weight children. Pediatr Pulmonol 2013:48:830-7. doi:10.1002/ppul.22676

52 Thunqvist $P$, Tufvesson E, Bjermer $L$, et al. Lung function after extremely preterm birth-A population-based cohort study (EXPRESS). Pediatr Pulmonol 2018:53:64-72. doi:10.1002/ppul.23919

53 Simpson S), Turkovic L, Wilson AC, et al. Lung function trajectories throughout childhood in survivors of very preterm birth: a longitudinal cohort study. Lancet Child Adolesc Health 2018;2:3509. doi:10.1016/S2352-4642(18)30064-6

54 Um-Bergström P, Hallberg J, Thunqvist P, et al. Lung function development after preterm birth in relation to severity of Bronchopulmonary dysplasia. BMC Pulm Med 2017;17:97. doi:10.1186/s12890-017-0441-3

55 Zivanovic S, Peacock J, Alcazar-Paris M, et al. Late outcomes of a randomized trial of high-frequency oscillation in neonates. N Engl Med 2014;370:1121-30. doi:10.1056/NEJMoa1309220 
56 Stevens TP, Finer NN, Carlo WA, et al, SUPPORT Study Group of the Eunice Kennedy Shriver National Institute of Child Health and Human Development Neonatal Research Network. Respiratory outcomes of the surfactant positive pressure and oximetry randomized trial (SUPPORT). J Pediatr 2014;165:240-249.e4. doi:10.1016/j. ipeds.2014.02.054

57 Duijts L, van Meel ER, Moschino L, et al. European Respiratory Society guideline on long-term management of children with bronchopulmonary dysplasia. Eur Respir / 2020;55:1900788. doi:10.1183/13993003.00788-2019

58 Vanhaverbeke K, Van Eyck A, Van Hoorenbeeck K, et al. Lung imaging in bronchopulmonary dysplasia: a systematic review. Respir Med 2020;171:106101. doi:10.1016/j.rmed.2020.106101

59 Hyödynmaa E, Korhonen P, Ahonen S, Luukkaala T, Tammela $O$. Frequency and clinical correlates of radiographic patterns of bronchopulmonary dysplasia in very low birth weight infants by term age. Eur J Pediatr 2012;171:95-102. doi:10.1007/s00431-0111486-6

60 Arai H, Ito T, Ito M, Ota S, Takahashi T, et al, Neonatal Research Network of Japan. Impact of chest radiography-based definition of bronchopulmonary dysplasia. Pediatr Int 2019;61:258-63. doi:10.1111/ped.13786

61 Greenough A, Thomas M, Dimitriou G, et al. Prediction of outcome from the chest radiograph appearance on day 7 of very prematurely born infants. EurJ Pediatr 2004;163:14-8. doi:10.1007/s00431003-1332-6

62 Kim HR, Kim JY, Yun B, Lee B, Choi CW, Kim BI. Interstitial pneumonia pattern on day 7 chest radiograph predicts bronchopulmonary dysplasia in preterm infants. BMC Pediatr 2017;17:125. doi:10.1186/s12887-017-0881-1

63 May C, Prendergast M, Salman S, Rafferty GF, Greenough A. Chest radiograph thoracic areas and lung volumes in infants developing bronchopulmonary dysplasia. Pediatr Pulmonol 2009;44:80-5. doi:10.1002/ppul.20952

64 Dassios T, Curley A, Krokidis M, Morley C, Ross-Russell R. Correlation of radiographic thoracic area and oxygenation impairment in bronchopulmonary dysplasia. Respir Physiol Neurobiol 2016;220:40-5. doi:10.1016/j.resp.2015.09.009

65 Boechat MC, Mello RR, Silva KS, et al. A computed tomography scoring system to assess pulmonary disease among premature infants. Sao Paulo Med J 2010;128:328-35. doi:10.1590/S151631802010000600004

66 Ochiai M, Hikino S, Yabuuchi H, et al. A new scoring system for computed tomography of the chest for assessing the clinical status of bronchopulmonary dysplasia. J Pediatr 2008;152:90-5, 95.e1-3. doi:10.1016/j.jpeds.2007.05.043

67 van Mastrigt E, Kakar E, Ciet P, et al. Structural and functional ventilatory impairment in infants with severe bronchopulmonary dysplasia. Pediatr Pulmonol 2017:52:1029-37. doi:10.1002/ppul.23696

68 Shin SM, Kim WS, Cheon JE, et al. Bronchopulmonary dysplasia: new high resolution computed tomography scoring system and correlation between the high resolution computed tomography score and clinical severity. Korean / Radiol 2013;14:350-60. doi:10.3348/ kjr.2013.14.2.350

69 Alonso-Ojembarrena A, Lubián-López SP. Lung ultrasound score as early predictor of bronchopulmonary dysplasia in very low birth weight infants. Pediatr Pulmonol 2019;54:1404-9. doi:10.1002/ppul.24410

70 Alonso-Ojembarrena A, Lechuga-Sancho AM, Morales-Arandojo P. Acuñas-Soto S, López-de-Francisco R, Lubián-López SP. Lung ultrasound score and diuretics in preterm infants born before 32 weeks: A pilot study. Pediatr Pulmonol 2020;55:3312-8. doi:10.1002/ppul.25098

71 Walkup LL, Higano NS, Woods JC. Structural and functional pulmonary magnetic resonance imaging in pediatrics - from the neonate to the young adult. Acad Radiol 2019;26:424-30. doi:10.1016/j. acra.2018.08.006

72 Hahn AD, Higano NS, Walkup LL, et al. Pulmonary MRI of neonates in the intensive care unit using 3D ultrashort echo time and a small footprint MRI system. J Magn Reson Imaging 2017;45:463-71. doi:10.1002/jmri.25394

73 Gouwens KR, Higano NS, Marks KT, et al. MRI evaluation of regional lung tidal volumes in severe neonatal bronchopulmonary dysplasia. Am J Respir Crit Care Med 2020;202:1024-31. doi:10.1164/ rccm.202001-02130C

74 Gunatilaka CC, Higano NS, Hysinger EB, et al. Increased work of breathing due to tracheomalacia in neonates. Ann Am Thorac Soc 2020;17:1247-56. doi:10.1513/AnnalsATS.202002-1620C

75 Förster K, Ertl-Wagner B, Ehrhardt $\mathrm{H}$, et al. Altered relaxation times in MRI indicate bronchopulmonary dysplasia. Thorax 2020;75:184-7. doi:10.1136/thoraxinl-2018-212384

76 Bhandari A, Bhandari V. Biomarkers in bronchopulmonary dysplasia. Paediatr Respir Rev 2013;14:173-9.

77 Lal CV, Bhandari V, Ambalavanan N. Genomics, microbiomics, proteomics, and metabolomics in bronchopulmonary dysplasia. Semin Perinatol 2018;42:425-31. doi:10.1053/j. semperi.2018.09.004

78 Gentle SJ, Lal CV. Predicting BPD: lessons learned from the airway microbiome of preterm infants. Front Pediatr 2020;7:564. doi:10.3389/fped.2019.00564

79 Pammi M, Lal CV, Wagner BD, et al. Airway microbiome and development of bronchopulmonary dysplasia in preterm infants: a systematic review. J Pediatr 2019;204:126-133.e2. doi:10.1016/j. jpeds.2018.08.042

80 Lal CV, Ambalavanan N. Biomarkers, early diagnosis, and clinical predictors of bronchopulmonary dysplasia. Clin Perinatol 2015;42:739-54. doi:10.1016/j.clp.2015.08.004

81 Lal CV, Ambalavanan N. Cellular and humoral biomarkers of Bronchopulmonary Dysplasia. Early Hum Dev 2017; 105:35-9. doi:10.1016/j.earlhumdev.2016.12.003

82 Arjaans S, Wagner BD, Mourani PM, et al. Early angiogenic proteins associated with high risk for bronchopulmonary dysplasia and pulmonary hypertension in preterm infants. Am J Physiol Lung Cell Mol Physiol 2020;318:L644-54. doi:10.1152/ajplung.00131.2019

83 Liao J, Kapadia VS, Brown LS, et al. The NLRP3 inflammasome is critically involved in the development of bronchopulmonary dysplasia. Nat Commun 2015;6:8977. doi:10.1038/ncomms9977

84 La Frano MR, Fahrmann JF, Grapov D, et al. Umbilical cord blood metabolomics reveal distinct signatures of dyslipidemia prior to bronchopulmonary dysplasia and pulmonary hypertension. Am Physiol Lung Cell Mol Physiol 2018;315:L870-81. doi:10.1152/ ajplung.00283.2017

85 Lal CV, Kandasamy J, Dolma K, et al. Early airway microbia metagenomic and metabolomic signatures are associated with development of severe bronchopulmonary dysplasia. Am J Physiol Lung Cell Mol Physiol 2018;315:L810-5. doi:10.1152/ ajplung.00085.2018

86 Piersigilli F, Lam TT, Vernocchi P, et al. Identification of new biomarkers of bronchopulmonary dysplasia using metabolomics. Metabolomics 2019;15:20. doi:10.1007/s11306-019-1482-9

87 Rogosch T, Herrmann N, Maier RF, et al. Detection of bloodstream infections and prediction of bronchopulmonary dysplasia in preterm neonates with an electronic nose. J Pediatr 2014;165:622-4. doi:10.1016/j.jpeds.2014.04.049

88 Bhattacharya S, Go D, Krenitsky DL, et al. Genome-wide transcriptional profiling reveals connective tissue mast cell accumulation in bronchopulmonary dysplasia. Am J Respir Crit Care Med 2012;186:349-58 doi:10.1164/rccm.201203-04060C

89 Syed M, Das P, Pawar A, et al. Hyperoxia causes miR-34amediated injury via angiopoietin-1 in neonatal lungs. Nat Commun 2017;8:1173. doi:10.1038/s41467-017-01349-y

90 Foglia EE, Jensen EA, Kirpalani H. Delivery room interventions to prevent bronchopulmonary dysplasia in extremely preterm infants. J Perinatol 2017;37:1171-9. doi:10.1038/ip.2017.74

91 Saugstad OD, Ramji S, Vento M. Resuscitation of depressed newborn infants with ambient air or pure oxygen: a meta-analysis. Biol Neonate 2005;87:27-34. doi:10.1159/000080950

92 Oei IL, Vento M. Is There a "right" amount of oxygen for preterm infant stabilization at birth?Front Pediatr 2019;7:354. doi:10.3389/ fped.2019.00354

93 Oei IL, Vento M, Rabi Y, et al. Higher or lower oxygen for delivery room resuscitation of preterm infants below 28 completed weeks gestation: a meta-analysis. Arch Dis Child Fetal Neonatal Ed 2017;102:F24-30. doi:10.1136/archdischild-2016-310435

94 Kapadia VS, Chalak LF, Sparks JE, Allen JR, Savani RC, Wyckoff MH. Resuscitation of preterm neonates with limited versus high oxygen strategy. Pediatrics 2013;132:e1488-96. doi:10.1542/peds.20130978

95 Oei JL, Finer NN, Saugstad OD, et al. Outcomes of oxygen saturation targeting during delivery room stabilisation of preterm infants. Arch Dis Child Fetal Neonatal Ed 2018;103:F446-54. doi:10.1136/ archdischild-2016-312366

96 Askie LM, Darlow BA, Davis PG, et al. Effects of targeting lower versus higher arterial oxygen saturations on death or disability in preterm infants. Cochrane Database Syst Rev 2017:4:CD011190. doi:10.1002/14651858.CD011190.pub2

97 Manja V, Lakshminrusimha S, Cook DJ. Oxygen saturation target range for extremely preterm infants: a systematic review and meta-analysis. JAMA Pediatr 2015;169:332-40. doi:10.1001/ jamapediatrics.2014.3307

98 Kirpalani H, Ratcliffe SJ, Keszler M, et al, SAlL Site Investigators. Effect of sustained inflations vs intermittent positive pressure ventilation on bronchopulmonary dysplasia or death among extremely preterm infants: the SAIL randomized clinical trial. JAMA 2019;321:1165-75. doi:10.1001/jama.2019.1660

99 Soll R, Ozek E. Prophylactic protein free synthetic surfactant for preventing morbidity and mortality in preterm infants. Cochrane Database Syst Rev 2010;1:CD001079. doi:10.1002/14651858. CD001079.pub2 
100 Morley CJ, Davis PG, Doyle LW, Brion LP, Hascoet JM, Carlin JB, COIN Trial Investigators. Nasal CPAP or intubation at birth for very preterm infants. N Engl / Med 2008;358:700-8. doi:10.1056/ NEJMoa072788

101 Finer NN, Carlo WA, Walsh MC, et al, SUPPORT Study Group of the Eunice Kennedy Shriver NICHD Neonatal Research Network Early CPAP versus surfactant in extremely preterm infants. N Engl J Med 2010;362:1970-9. doi:10.1056/NEJMoa0911783

102 Dunn MS, Kaempf J, de Klerk A, et al, Vermont Oxford Network DRM Study Group. Randomized trial comparing 3 approaches to the initial respiratory management of preterm neonates. Pediatrics 2011;128:e1069-76. doi:10.1542/peds.2010-3848

103 Schmölzer GM, Kumar M, Pichler G, Aziz K, O’Reilly M, Cheung PY. Non-invasive versus invasive respiratory support in preterm infants at birth: systematic review and meta-analysis. BMJ 2013;347:f5980. doi:10.1136/bmi.f5980

104 Isayama T, Chai-Adisaksopha C, McDonald SD. Noninvasive ventilation with vs without early surfactant to prevent chronic lung disease in preterm infants: a systematic review and meta-analysis. JAMA Pediatr 2015;169:731-9. doi:10.1001/jamapediatrics.2015.0510

105 Herting E, Härtel C, Göpel W. Less invasive surfactant administration: best practices and unanswered questions. Curr Opin Pediatr 2020:32:228-34. doi:10.1097/MOP.0000000000000878

106 Kribs A, Roll C, Göpel W, et al, NINSAPP Trial Investigators. Nonintubated surfactant application vs conventional therapy in extremely preterm infants: a randomized clinical trial. JAMA Pediatr 2015;169:723-30. doi:10.1001/jamapediatrics.2015.0504

107 Ramos-Navarro C, Sánchez-Luna M, Zeballos-Sarrato S, GonzálezPacheco N. Three-year perinatal outcomes of less invasive beractant administration in preterm infants with respiratory distress syndrome. J Matern Fetal Neonatal Med 2020;33:2704-10. doi:10.1080/1476 7058.2018 .1557633

108 Isayama T, Iwami H, McDonald S, Beyene J. Association of noninvasive ventilation strategies with mortality and bronchopulmonary dysplasia among preterm Infants: a systematic review and meta-analysis. IAMA 2016:316:611-24. doi:10.1001/jama.2016.10708

109 Härtel C, Paul P, Hanke K, et al. Less invasive surfactant administration and complications of preterm birth. Sci Rep 2018;8:8333. doi:10.1038/s41598-018-26437-x

110 Ammari A, Suri M, Milisavljevic V, et al. Variables associated with the early failure of nasal CPAP in very low birth weight infants. J Pediatr 2005;147:341-7. doi:10.1016/j.jpeds.2005.04.062

111 Dargaville PA, Gerber A, Johansson S, et al, Australian and New Zealand Neonatal Network. Incidence and outcome of CPAP failure in preterm infants. Pediatrics 2016;138:e20153985. doi:10.1542/ peds.2015-3985

112 Gupta S, Donn SM. Continuous positive airway pressure: Physiology and comparison of devices. Semin Fetal Neonatal Med 2016;21:20411. doi:10.1016/i.siny.2016.02.009

113 Bharadwaj SK, Alonazi A, Banfield L, Dutta S, Mukerji A. Bubble versus other continuous positive airway pressure forms: a systematic review and meta-analysis. Arch Dis Child Fetal Neonatal Ed 2020;105:52631. doi:10.1136/archdischild-2019-318165

114 Bancalari E, Claure N. The evidence for non-invasive ventilation in the preterm infant. Arch Dis Child Fetal Neonatal Ed 2013;98:F98-102. doi:10.1136/archdischild-2011-301266

115 Lemyre B, Laughon M, Bose C, Davis PG. Early nasal intermittent positive pressure ventilation (NIPPV) versus early nasal continuous positive airway pressure (NCPAP) for preterm infants. Cochrane Database Syst Rev 2016;12:CD005384. doi:10.1002/14651858. CD005384.pub2

116 Meneses J, Bhandari V, Alves JG. Nasal intermittent positive-pressure ventilation vs nasal continuous positive airway pressure for preterm infants with respiratory distress syndrome: a systematic review and meta-analysis. Arch Pediatr Adolesc Med 2012;166:372-6. doi:10.1001/archpediatrics.2011.1142

117 Kirpalani H, Millar D, Lemyre B, Yoder BA, Chiu A, Roberts RS, et al, NIPPV Study Group. A trial comparing noninvasive ventilation strategies in preterm infants. N Engl J Med 2013;369:611-20. doi:10.1056/NEJMoa1214533

118 Keszler M. Volume-targeted ventilation: one size does not fit all. Evidence-based recommendations for successful use. Arch Dis Child Fetal Neonatal Ed 2019;104:F108-12. doi:10.1136/ archdischild-2017-314734

119 Klingenberg C, Wheeler KI, McCallion N, Morley CJ, Davis PG. Volumetargeted versus pressure-limited ventilation in neonates. Cochrane Database Syst Rev 2017;10:CD003666

120 Cools F, Askie LM, Offringa M, et al, PreVILIG collaboration. Elective high-frequency oscillatory versus conventional ventilation in preterm infants: a systematic review and meta-analysis of individual patients' data. Lancet 2010;375:2082-91. doi:10.1016/S01406736(10)60278-4

121 Harris C, Bisquera A, Lunt A, Peacock JL, Greenough A. Outcomes of the neonatal trial of high-frequency oscillation at 16 to 19 years. $N$ Engl J Med 2020;383:689-91. doi:10.1056/NEJMc2008677
122 Laughon MM, Langer JC, Bose CL, et al, Eunice Kennedy Shriver National Institute of Child Health and Human Development Neonatal Research Network. Prediction of bronchopulmonary dysplasia by postnatal age in extremely premature infants. Am J Respir Crit Care Med 2011;183:1715-22. doi:10.1164/rccm.201101-00550C

123 Berger J, Mehta P, Bucholz E, Dziura J, Bhandari V. Impact of early extubation and reintubation on the incidence of bronchopulmonary dysplasia in neonates. Am J Perinatol 2014;31:1063-72. doi:10.1055/s-0034-1371702

124 Leroy S, Caumette E, Waddington C, Hébert A, Brant R, Lavoie PM. A time-based analysis of inflammation in infants at risk of bronchopulmonary dysplasia. J Pediatr 2018;192:60-65.e1. doi:10.1016/j.jpeds.2017.09.011

125 Jensen EA, DeMauro SB, Kornhauser M, Aghai ZH, Greenspan JS, Dysart KC. Effects of multiple ventilation courses and duration of mechanical ventilation on respiratory outcomes in extremely lowbirth-weight infants. JAMA Pediatr 2015;169:1011-7. doi:10.1001/ jamapediatrics.2015.2401

126 Robbins M, Trittmann J, Martin E, Reber KM, Nelin L, Shepherd E. Early extubation attempts reduce length of stay in extremely preterm infants even if re-intubation is necessary. I Neonatal Perinatal Med 2015;8:91-7. doi:10.3233/NPM-15814061

127 Shalish W, Kanbar L, Kovacs L, et al. The impact of time interval between extubation and reintubation on death or bronchopulmonary dysplasia in extremely preterm infants. J Pediatr 2019;205:70-76.e2. doi:10.1016/i.jpeds.2018.09.062

128 Schmidt B, Roberts RS, Davis P, et al, Caffeine for Apnea of Prematurity Trial Group. Caffeine therapy for apnea of prematurity. N Engl / Med 2006;354:2112-21. doi:10.1056/NEJMoa054065

129 Jensen EA, Foglia EE, Schmidt B. Evidence-based pharmacologic therapies for prevention of bronchopulmonary dysplasia: Application of the grading of recommendations assessment, development, and evaluation methodology. Clin Perinatol 2015;42:755-79. doi:10.1016/j.clp.2015.08.005

130 Schmidt B, Roberts RS, Anderson PJ, et al, Caffeine for Apnea of Prematurity (CAP) Trial Group. Academic performance, motor function, and behavior 11 years after neonatal caffeine citrate therapy for apnea of prematurity: an 11-year follow-up of the CAP randomized clinical trial. JAMA Pediatr 2017;171:564-72. doi:10.1001/jamapediatrics.2017.0238

131 Doyle LW, Ranganathan S, Cheong JLY. Neonatal caffeine treatment and respiratory function at 11 years in children under $1,251 \mathrm{~g}$ at birth. Am / Respir Crit Care Med 2017;196:1318-24. doi:10.1164/ rccm.201704-07670C

132 Davis PG, Schmidt B, Roberts RS, et al, Caffeine for Apnea of Prematurity Trial Group. Caffeine for Apnea of Prematurity trial: benefits may vary in subgroups. J Pediatr 2010;156:382-7. doi:10.1016/j.jpeds.2009.09.069

133 Lodha A, Seshia M, McMillan DD, et al, Canadian Neonatal Network. Association of early caffeine administration and neonatal outcomes in very preterm neonates. JAMA Pediatr 2015;169:33-8. doi:10.1001/jamapediatrics.2014.2223

134 Lodha A, Entz R, Synnes A, et al, investigators of the Canadian Neonatal Network (CNN) and the Canadian Neonatal Follow-up Network (CNFUN). Early caffeine administration and neurodevelopmental outcomes in preterm infants. Pediatrics 2019;143:e20181348. doi:10.1542/peds.2018-1348

135 Doyle LW, Cheong JL, Ehrenkranz RA, Halliday HL. Early ( 8 days) systemic postnatal corticosteroids for prevention of bronchopulmonary dysplasia in preterm infants. Cochrane Database Syst Rev 2017;10:CD001146. doi:10.1002/14651858.CD001146.pub5

136 Doyle LW, Cheong JL, Ehrenkranz RA, Halliday HL. Late (> 7 days) systemic postnatal corticosteroids for prevention of bronchopulmonary dysplasia in preterm infants. Cochrane Database Syst Rev 2017;10:CD001145. doi:10.1002/14651858.CD001145. pub4

137 Shaffer ML, Baud O, Lacaze-Masmonteil T, Peltoniemi OM, Bonsante F, Watterberg KL. Effect of prophylaxis for early adrenal insufficiency using low-dose hydrocortisone in very preterm infants: an individual patient data meta-analysis. J Pediatr 2019;207:136-142.e5. doi:10.1016/j.jpeds.2018.10.004

138 Baud O, Maury L, Lebail F, et al, PREMILOC trial study group. Effect of early low-dose hydrocortisone on survival without bronchopulmonary dysplasia in extremely preterm infants (PREMILOC): a doubleblind, placebo-controlled, multicentre, randomised trial. Lancet 2016;387:1827-36. doi:10.1016/S0140-6736(16)00202-6

139 Onland W, Cools F, Kroon A, et al, STOP-BPD Study Group. Effect of hydrocortisone therapy initiated 7 to 14 days after birth on mortality or bronchopulmonary dysplasia among very preterm infants receiving mechanical ventilation: a randomized clinical trial. JAMA 2019;321:354-63. doi:10.1001/jama.2018.21443

140 Guyatt GH, Oxman AD, Vist GE, et al, GRADE Working Group. GRADE: an emerging consensus on rating quality of evidence and strength of recommendations. BMJ 2008;336:924-6. doi:10.1136/ bmj.39489.470347.AD 
141 Doyle LW, Halliday HL, Ehrenkranz RA, Davis PG, Sinclair JC. Impact of postnatal systemic corticosteroids on mortality and cerebral palsy in preterm infants: effect modification by risk for chronic lung disease. Pediatrics 2005;115:655-61. doi:10.1542/peds.2004-1238

142 Doyle LW, Davis PG, Morley C), McPhee A, Carlin JB, Investigators DS, et al, DART Study Investigators. Low-dose dexamethasone facilitates extubation among chronically ventilator-dependent infants: a multicenter, international, randomized, controlled trial. Pediatrics 2006;117:75-83. doi:10.1542/peds.2004-2843

143 Doyle LW, Davis PG, Morley CJ, McPhee A, Carlin JB, Investigators DS, et al, DART Study Investigators. Outcome at 2 years of age of infants from the DART study: a multicenter, international, randomized, controlled trial of low-dose dexamethasone. Pediatrics 2007;119:716-21. doi:10.1542/peds.2006-2806

144 Watterberg KL, American Academy of Pediatrics. Committee on Fetus and Newborn. Policy statement--postnatal corticosteroids to prevent or treat bronchopulmonary dysplasia. Pediatrics 2010;126:800-8. doi:10.1542/peds.2010-1534

145 Carlo WA, McDonald SA, Fanaroff AA, et al, Eunice Kennedy Shriver National Institute of Child Health and Human Development Neonatal Research Network. Association of antenatal corticosteroids with mortality and neurodevelopmental outcomes among infants born at 22 to 25 weeks' gestation. JAMA 2011;306:2348-58. doi:10.1001/ jama.2011.1752

146 Peltoniemi O, Kari MA, Heinonen K, et al. Pretreatment cortisol values may predict responses to hydrocortisone administration for the prevention of bronchopulmonary dysplasia in high-risk infants. J Pediatr 2005;146:632-7. doi:10.1016/j.jpeds.2004.12.040

147 Bonsante F, Latorre G, lacobelli S, et al. Early low-dose hydrocortisone in very preterm infants: a randomized, placebo-controlled trial. Neonatology 2007;91:217-21. doi:10.1159/000098168

148 Baud O, Trousson C, Biran V, Leroy E, Mohamed D, Albert C. PREMILOC Trial Group. Association between early lowdose hydrocortisone therapy in extremely preterm neonates and neurodevelopmental outcomes at 2 years of age. JAMA 2017:317:1329-37. doi:10.1001/jama.2017.2692

149 Héneau A, Guimiot F, Mohamed D, Rideau Batista Novais A, Albert C, Baud O, PREMILOC Trial study group. Placental findings and effect of prophylactic hydrocortisone in extremely preterm infants. Pediatrics 2018;141:e20171788. doi:10.1542/peds.2017-1788

150 Bassler D. Inhaled budesonide for the prevention of bronchopulmonary dysplasia. J Matern Fetal Neonatal Med 2017:30:2372-4. doi:10.1080/14767058.2016.1248937

151 Bassler D, Shinwell ES, Hallman M, et al, Neonatal European Study of Inhaled Steroids Trial Group. Long-term effects of inhaled budesonide for bronchopulmonary dysplasia. N Engl / Med 2018;378:148-57. doi:10.1056/NEJMoa1708831

152 Laughon MM, Chantala K, Aliaga S, et al. Diuretic exposure in premature infants from 1997 to 2011. Am / Perinatol 2015:32:49-56.

153 Tan C, Sehgal K, Sehgal K, Krishnappa SB, Sehgal A. Diuretic use in infants with developing or established chronic lung disease: A practice looking for evidence. J Paediatr Child Health 2020;56:118993. doi:10.1111/jpc.14877

154 Blaisdell CJ, Troendle J, Zajicek A, Prematurity and Respiratory Outcomes Program. Program PaRO. Acute responses to diuretic therapy in extremely low gestational age newborns: results from the prematurity and respiratory outcomes program cohort study. Pediatr 2018;197:42-47.e1. doi:10.1016/j.jpeds.2018.01.066

155 Greenberg RG, Gayam S, Savage D, et al, Best Pharmaceuticals for Children Act-Pediatric Trials Network Steering Committee. Furosemide exposure and prevention of bronchopulmonary dysplasia in premature infants. J Pediatr 2019;208:134-140.e2. doi:10.1016/i.jpeds.2018.11.043

156 Tan C, Sehgal K, Sehgal K, Krishnappa SB, Sehgal A. Diuretic use in infants with developing or established chronic lung disease: A practice looking for evidence. J Paediatr Child Health 2020;56:118993. doi:10.1111/jpc.14877

157 Segar JL. Rethinking furosemide use for infants with bronchopulmonary dysplasia. Pediatr Pulmonol 2020;55:1100-3. doi:10.1002/ppul.24722

158 Gimpel C, Krause A, Franck P, Krueger M, von Schnakenburg C. Exposure to furosemide as the strongest risk factor fo nephrocalcinosis in preterm infants. Pediatr Int 2010;52:51-6. doi:10.1111/j.1442-200X.2009.02886.x

159 Jensen EA, White AM, Liu P, et al. Determinants of severe metabolic bone disease in very low-birth-weight infants with severe bronchopulmonary dysplasia admitted to a tertiary referral center. Am J Perinatol 2016;33:107-13.

160 Albertine $\mathrm{KH}$. Progress in understanding the pathogenesis of BPD using the baboon and sheep models. Semin Perinatol 2013;37:608. doi:10.1053/j.semperi.2013.01.001

$161 \mathrm{Ng}$ G, da Silva O, Ohlsson A. Bronchodilators for the prevention and treatment of chronic lung disease in preterm infants. Cochrane Database Syst Rev 2016;12:CD003214. doi:10.1002/14651858. CD003214.pub3
162 Uberos J, Jimenez-Montilla S, Molina-Oya M, García-Serrano JL. Early energy restriction in premature infants and bronchopulmonary dysplasia: a cohort study. Br I Nutr 2020:123:1024-31. doi:10.1017/S0007114520000240

163 Schanler RJ, Lau C, Hurst NM, Smith EO. Randomized trial of donor human milk versus preterm formula as substitutes for mothers' own milk in the feeding of extremely premature infants. Pediatrics 2005;116:400-6. doi:10.1542/peds.2004-1974

164 Dicky O, Ehlinger V, Montjaux N, et al, EPIPAGE 2 Nutrition Study Group, EPINUTRI Study Group. Policy of feeding very preterm infants with their mother's own fresh expressed milk was associated with a reduced risk of bronchopulmonary dysplasia. Acto Paediatr 2017:106:755-62. doi:10.1111/apa.13757

165 Sheth S, Goto L, Bhandari V, Abraham B, Mowes A. Factors associated with development of early and late pulmonary hypertension in preterm infants with bronchopulmonary dysplasia. Perinatol 2020;40:138-48. doi:10.1038/s41372-019-0549-9

166 Abman SH, Collaco JM, Shepherd EG, et al, Bronchopulmonary Dysplasia Collaborative. Interdisciplinary care of children with severe bronchopulmonary dysplasia. J Pediatr 2017;181:12-28.e1. doi:10.1016/j.jpeds.2016.10.082

167 Bhandari V, Bhandari A, Rajiv PK. Bronchopulmonary dysplasia. In: Rajiv PKVD, Lakshminrusimha S, eds. Essentials of neonatal ventilation. Elsevier Health Sciences, 2018: 461-90.

168 Levit OL, Shabanova V, Bazzy-Asaad A, Bizzarro MJ, Bhandari V. Risk factors for tracheostomy requirement in extremely low birth weight infants. J Matern Fetal Neonatal Med 2018;31:447-52. doi:10.1080/ 14767058.2017.1287895

169 Luo J, Shepard S, Nilan K, et al. Improved growth and developmental activity post tracheostomy in preterm infants with severe BPD. Pediatr Pulmonol 2018;53:1237-44. doi:10.1002/ppul.24087

170 Baker CD. Long-term ventilation for children with chronic lung disease of infancy. Curr Opin Pediatr 2019;31:357-66. doi:10.1097/ MOP.0000000000000757

171 Koltsida G, Konstantinopoulou S. Long term outcomes in chronic lung disease requiring tracheostomy and chronic mechanical ventilation. Semin Fetal Neonatal Med 2019;24:101044. doi:10.1016/j. siny.2019.101044

172 Bhandari A, Schramm CM, Kimble C, Pappagallo M, Hussain N. Effect of a short course of prednisolone in infants with oxygen-dependent bronchopulmonary dysplasia. Pediatrics 2008;121:e344-9. doi:10.1542/peds.2006-3668

173 Bamat NA, Nelin TD, Eichenwald EC, et al. Loop diuretics in severe bronchopulmonary dysplasia: cumulative use and associations with mortality and age at discharge. J Pediatr 2021;231:43-49.e3. doi:10.1016/j.jpeds.2020.10.073

174 Anderson C, Hillman NH. Bronchopulmonary dysplasia: when the very preterm baby comes home. Mo Med 2019;116:117-22.

175 Bhandari A, Panitch H. An update on the post-NICU discharge management of bronchopulmonary dysplasia. Semin Perinatol 2018;42:471-7. doi:10.1053/j.semperi.2018.09.011

176 Saletti A, Stick S, Doherty D, Simmer K. Home oxygen therapy after preterm birth in Western Australia. J Paediatr Child Health 2004;40:519-23. doi:10.1111/j.1440-1754.2004.00455.x

177 Kamlin C, Davis PG. Long versus short inspiratory times in neonates receiving mechanical ventilation. Cochrane Database Syst Rev 2004:4:CD004503

178 Ambalavanan N, Carlo WA. Ventilatory strategies in the prevention and management of bronchopulmonary dysplasia. Semin Perinatol 2006:30:192-9. doi:10.1053/i.semperi.2006.05.006

179 Thome UH, Ambalavanan N. Permissive hypercapnia to decrease lung injury in ventilated preterm neonates. Semin Fetal Neonatal Med 2009:14:21-7. doi:10.1016/i.siny.2008.08.005

180 Bhandari V. Nasal intermittent positive pressure ventilation in the newborn: review of literature and evidence-based guidelines. J Perinatol 2010;30:505-12. doi:10.1038/ip.2009.165

181 Yeh TF, Chen CM, Wu SY, et al. Intratracheal Administration of Budesonide/Surfactant to Prevent Bronchopulmonary Dysplasia. Am J Respir Crit Care Med 2016;193:86-95. doi:10.1164/rccm.201505 08610C

182 Tyson JE, Wright LL, Oh W, et al, National Institute of Child Health and Human Development Neonatal Research Network. Vitamin A supplementation for extremely-low-birth-weight infants. N EnglJ Med 1999;340:1962-8. doi:10.1056/NEJM199906243402505

183 Al-Jebawi Y, Agarwal N, Groh Wargo S, Shekhawat P, Mhanna MJ. Low caloric intake and high fluid intake during the first week of life are associated with the severity of bronchopulmonary dysplasia in extremely low birth weight infants. J Neonatal Perinatal Med 2020;13:207-14. doi:10.3233/NPM-190267

184 Cheong JLY, Olsen JE, Huang L, et al, Members of the Victorian Infant Collaborative Study Group. Changing consumption of resources for respiratory support and short-term outcomes in four consecutive geographical cohorts of infants born extremely preterm over 25 years since the early 1990s. BMJ Open 2020;10:e037507. doi:10.1136/ bmjopen-2020-037507 
185 Harmon HM, Jensen EA, Tan S, et al, Eunice Kennedy Shriver National Institute of Child Health and Human Development Neonatal Research Network. Timing of postnatal steroids for bronchopulmonary dysplasia: association with pulmonary and neurodevelopmental outcomes. J Perinatol 2020;40:616-27. doi:10.1038/s41372-0200594-4

186 Thome UH, Genzel-Boroviczeny O, Bohnhorst B, et al, PHELBI Study Group. Permissive hypercapnia in extremely low birthweight infants (PHELBI): a randomised controlled multicentre trial. Lancet Respir Med 2015;3:534-43. doi:10.1016/S2213-2600(15)00204-0

187 Narayan O, Bentley A, Mowbray K, et al. Updated cost-effectiveness analysis of palivizumab (Synagis) for the prophylaxis of respiratory syncytial virus in infant populations in the UK. J Med Econ 2020;23:1640-52. doi:10.1080/13696998.2020.1836923

188 Cummings JJ, Polin RA, COMMITTEE ON FETUS AND NEWBORN. NEWBORN COFA. Oxygen targeting in extremely low birth weight infants. Pediatrics 2016;138:e20161576. doi:10.1542/peds.20161576

189 Sweet DG, Carnielli V, Greisen G, et al. European consensus guidelines on the management of respiratory distress syndrome-2019 update. Neonatology 2019;115:432-50. doi:10.1159/000499361

190 Polin RA, Carlo WA, Committee on Fetus and Newborn, American Academy of Pediatrics. Surfactant replacement therapy for preterm and term neonates with respiratory distress. Pediatrics 2014;133:156-63. doi:10.1542/peds.2013-3443

191 Abman SH, Ivy DD, Archer SL, Wilson K, AHA/ATS Joint Guidelines for Pediatric Pulmonary Hypertension Committee. Committee AAJGFPPH. Executive summary of the American Heart Association and American Thoracic Society joint guidelines for pediatric pulmonary hypertension. Am J Respir Crit Care Med 2016;194:898-906. doi:10.1164/rccm.201606-1183ST

192 Keller RL, Feng R, DeMauro SB, et al, Prematurity and Respiratory Outcomes Program. Bronchopulmonary dysplasia and perinatal characteristics predict 1-year respiratory outcomes in newborns born at extremely low gestational age: a prospective cohort study. J Pediatr 2017;187:89-97.e3. doi:10.1016/j.jpeds.2017.04.026
193 McEvoy CT, Jain L, Schmidt B, Abman S, Bancalari E, Aschner IL. Bronchopulmonary dysplasia: NHLBI workshop on the primary prevention of chronic lung diseases. Ann Am Thorac Soc 2014;11(Suppl 3):S146-53. doi:10.1513/AnnalsATS.201312-424LD

194 Venkataraman R, Kamaluddeen M, Hasan SU, Robertson HL, Lodha A. Intratracheal Administration of Budesonide-Surfactant in Prevention of Bronchopulmonary Dysplasia in Very Low Birth Weight Infants: A Systematic Review and Meta-Analysis. Pediatr Pulmonol 2017:52:968-75. doi:10.1002/ppul.23680

195 Yeh TF, Lin HC, Chang CH, et al. Early intratracheal instillation of budesonide using surfactant as a vehicle to prevent chronic lung disease in preterm infants: a pilot study. Pediatrics 2008;121:e1310-8. doi:10.1542/peds.2007-1973

196 Hellström A, Ley D, Hansen-Pupp I, et al. Role of insulinlike growth factor 1 in fetal development and in the early postnatal life of premature infants. Am J Perinatol 2016;33:1067-71. doi:10.1055/s-0036-1586109

197 Ley D, Hallberg B, Hansen-Pupp I, et al, study team. rhIGF-1/ rhIGFBP-3 in preterm infants: a phase 2 randomized controlled trial. J Pediatr 2019;206:56-65.e8. doi:10.1016/j.jpeds.2018.10.033

198 Ahn SY, Park WS, Sung SI, Chang YS. Mesenchymal stem cell therapy for intractable neonatal disorders. Pediatr Neonatol 2021;62(Suppl 1):S16-21. doi:10.1016/i.pedneo.2020.11.007

199 Ahn SY, Chang YS, Lee MH, et al. Stem cells for bronchopulmonary dysplasia in preterm infants: A randomized controlled phase II trial. Stem Cells Transl Med 2021;10:1129-37. doi:10.1002/sctm.20-0330.

200 Steinhorn R, Davis JM, Göpel W, et al, International Neonatal Consortium. Chronic pulmonary insufficiency of prematurity: developing optimal endpoints for drug development. J Pediatr 2017;191:15-21.e1. doi:10.1016/j.jpeds.2017.08.006

Supplemental Table 1. Levels of Evidence and Recommendations for Clinical Use Based on the Guidelines Developed by the US Preventive Services Task Force 